\title{
Flow cytometric evaluation of physico-chemical impact on Gram-positive and Gram-negative bacteria
}

\author{
Antje Fröhling * and Oliver Schlüter \\ Quality and Safety of Food and Feed, Leibniz Institute for Agricultural Engineering Potsdam-Bornim e.V., Potsdam, Germany
}

OPEN ACCESS

Edited by:

Henry Jaeger,

University of Natural Resources and

Life Sciences, Vienna, Austria

Reviewed by:

Louis Coroller,

Université de Brest, France

Marija Zunabovic-Pichler,

University of Natural Resources and

Life Sciences, Vienna, Austria

*Correspondence:

Antje Fröhling,

Quality and Safety of Food and Feed,

Leibniz Institute for Agricultural

Engineering Potsdam, Max-Eyth-Allee

100, D-14469 Potsdam, Germany

afroehling@atb-potsdam.de

Specialty section:

This article was submitted to

Food Microbiology,

a section of the journal

Frontiers in Microbiology

Received: 17 April 2015

Accepted: 24 August 2015

Published: 24 September 2015

Citation:

Fröhling A and Schlüter O (2015) Flow

cytometric evaluation of

physico-chemical impact on

Gram-positive and Gram-negative

bacteria. Front. Microbiol. 6:939.

doi: 10.3389/fmicb.2015.00939
Since heat sensitivity of fruits and vegetables limits the application of thermal inactivation processes, new emerging inactivation technologies have to be established to fulfill the requirements of food safety without affecting the produce quality. The efficiency of inactivation treatments has to be ensured and monitored. Monitoring of inactivation effects is commonly performed using traditional cultivation methods which have the disadvantage of the time span needed to obtain results. The aim of this study was to compare the inactivation effects of peracetic acid (PAA), ozonated water $\left(\mathrm{O}_{3}\right)$, and cold atmospheric pressure plasma (CAPP) on Gram-positive and Gram-negative bacteria using flow cytometric methods. E. coli cells were completely depolarized after treatment (15s) with $0.25 \% \mathrm{PAA}$ at $10^{\circ} \mathrm{C}$, and after treatment $(10 \mathrm{~s})$ with $3.8 \mathrm{mg} \mathrm{I}^{-1} \mathrm{O}_{3}$ at $12^{\circ} \mathrm{C}$. The membrane potential of CAPP treated cells remained almost constant at an operating power of $20 \mathrm{~W}$ over a time period of $3 \mathrm{~min}$, and subsequently decreased within $30 \mathrm{~s}$ of further treatment. Complete membrane permeabilization was observed after $10 \mathrm{~s}$ $\mathrm{O}_{3}$ treatment, but treatment with PAA and CAPP did not completely permeabilize the cells within 2 and 4 min, respectively. Similar results were obtained for esterase activity. $\mathrm{O}_{3}$ inactivates cellular esterase but esterase activity was detected after 4 min CAPP treatment and 2 min PAA treatment. $L$. innocua cells and $P$. carotovorum cells were also permeabilized instantaneously by $\mathrm{O}_{3}$ treatment at concentrations of $3.8 \pm 1 \mathrm{mg}$ $I^{-1}$. However, higher membrane permeabilization of $L$. innocua and $P$. carotovorum than of $E$. coli was observed at CAPP treatment of $20 \mathrm{~W}$. The degree of bacterial damage due to the inactivation processes is highly dependent on treatment parameters as well as on treated bacteria. Important information regarding the inactivation mechanisms can be obtained by flow cytometric measurements and this enables the definition of critical process parameters.

Keywords: culturability, membrane potential, esterase activity, membrane permeabilization, cold atmospheric pressure plasma, peracetic acid, ozonated water 


\section{Introduction}

Perishable products are naturally contaminated with microorganisms including human pathogenic and spoilage bacteria. The level of contamination depends on the season and on the type of fruit and vegetables and ranges between 3 and $7 \mathrm{log}$ units per gram (Ölmez and Kretzschmar, 2009). The microbial load of perishables with human pathogenic bacteria is divers and often leads to foodborne diseases. The microbial load does not only consist of human pathogenic bacteria, there are also phyto pathogenic bacteria present on the fresh produce which can result in postharvest losses or reduced consumer acceptance due to reduced shelf-life. Kader (2005) estimated that one third of all fruits and vegetables produced is not consumed by humans. Throughout the world, the amount of postharvest losses is depending on commodities, production areas, and seasons (Kader, 2005). To minimize the risk of foodborne diseases and to improve microbial quality, decontamination of fresh produce is necessary. Washing of fruits and vegetables removes soil and dirt from the produce but only reduces microbial load by 1 or $2 \log$ units (Sapers, 2001). But washing can also be a potential source for microbial contamination of produce, e.g., pathogens can easily be distributed by the wash water along the processing chain (Doyle and Erickson, 2008). An additional 10 - to 100 -fold reduction of bacterial load can be achieved using disinfectants, but some disinfectants are only suitable for equipments, others can be used in direct washing of products (Beuchat, 1998). Thermal treatments are limited both by the requirements for the appropriate inactivation of pathogens demanding for temperatures far above $45^{\circ} \mathrm{C}$, and the negative impact on produce quality at these elevated temperatures (Schlüter et al., 2009). The disinfection of produce is therefore limited to non-thermal processes below $45^{\circ} \mathrm{C}$. Consequently, new emerging inactivation technologies have to be established to fulfill the requirements of food safety, whereas detailed knowledge about these inactivation methods is necessary to ensure efficacy of inactivation processes.

Peracetic acid (PAA) is also known as peroxyacetic acid, acetyl hydroxide or ethaneperoxoic acid. The peroxide of acetic acid is a strong oxidant and disinfectant. The commercially available PAA is a quaternary equilibrium mixture that consists of acetic acid, hydrogen peroxide, PAA, and water (Kitis, 2004). PAA can be used over a wide temperature range $\left(0-40^{\circ} \mathrm{C}\right)$, the efficiency of PAA is not affected by protein residues, it can be used with hard water, in cleaning-in-place processes and carbon dioxide saturated environments. Additionally, it is efficient over a wide range of $\mathrm{pH}$ (3.0-7.5) (Kunigk and Almeida, 2001). The decomposition products of PAA are water, oxygen, hydrogen peroxide, and acetic acid (Kitis, 2004; Wang et al., 2006). In the food processing industry (e.g., dairies, wineries, breweries, canneries, meat and poultry-processing plants, and beverage industry) peracetic acid (PAA) is used as disinfectant and for wastewater disinfection (Kitis, 2004; Luukkonen et al., 2014). PAA is used as disinfectant and recoloring agent in the pulp, textile, and paper industry (Koivunen and Heinonen-Tanski, 2005; El Shafie et al., 2009; Rasimus et al., 2011) as well as for the disinfection of ion exchangers and cooling towers and for pathogen reduction in sludge debulking, biosolids, and for the reduction of solid odors (Kitis, 2004; Koivunen and HeinonenTanski, 2005). The efficiency of PAA against bacteria on fresh fruits and vegetables as well as on fresh-cut fruits and vegetables was examined in various studies (Beuchat et al., 2004; Kim et al., 2006; Alvaro et al., 2009; Vandekinderen et al., 2009; Van De Velde et al., 2014).

With an oxidizing potential of $2.07 \mathrm{~V}$, ozone is the fifth in thermodynamic oxidation potential behind fluorine, chlorine trifluoride, atomic oxygen, and hydroxyl free radical (Graham, 1997). This oxidizing potential makes ozone the strongest disinfection agent available for the contact with foods (Mahapatra et al., 2005) and water and wastewater treatment (Graham, 1997). The solubility of ozone in water is dependent on several parameters. The temperature of the water, the bubble size and the presence of minerals or organic matter highly influences the solubility of ozone. The half-life of ozone in gaseous state is $12 \mathrm{~h}$ at room temperature and in pure, clean water $(\mathrm{pH} \mathrm{7-8)}$ the half-life is $20-30 \mathrm{~min}$ (Khadre and Yousef, 2001; Kim et al., 2003). The decomposition of ozone in solution is a stepwise fashion accompanied by the production of free radicals such as hydroperoxyl, hydroxyl, and superoxide. These free radicals have a great oxidizing power and the reactivity of ozone is attributed to these radicals. In the food industry ozone applications are related to decontamination of product surfaces, food plant equipment, reuse of waste water, and lowering biological oxygen demand (BOD) and chemical oxygen demand (COD) of food plant waste. Inactivation of contaminated microflora on meat, poultry, eggs, fish, fruits, vegetables, and dry food by ozone was met with mixed success (Guzel-Seydim et al., 2004). In fruit and vegetable processing ozone is applied in gaseous state and dissolved in water to improve food safety (Tiwari, 2012). Overviews of studies focusing on decontamination of food products by ozone are given by Perry and Yousef (2011), O’Donnell et al. (2012), and Miller et al. (2013).

Plasma treatment in which the treated surface temperature is kept below the temperature of thermal treatments can be defined as cold plasmas (Schlüter and Fröhling, 2014). Atmosphericpressure plasma sources used for microbial decontamination are commonly generated by corona discharge, dielectric barrier discharge, atmospheric pressure plasma jet, and MW-driven plasmas (Ehlbeck et al., 2011). Cold plasma treatment is of grown interest in food microbiology and in various studies the antimicrobial activity of cold plasma against Gram-negative and Gram-positive bacteria, yeast and fungi, biofilm formers, and endospores as well as the effects of plasma on biomolecules such as proteins and enzymes was shown (Laroussi, 2005; Vleugels et al., 2005; Brandenburg et al., 2007; Surowsky et al., 2013; Bußler et al., 2015a,b; Misra et al., 2015). The inactivation of food-related microorganisms by plasma treatment is mainly performed using model systems but the evaluation of plasma effects on microorganisms attached to food surfaces is more and more of interest. Surowsky et al. (2014b) summarized the interactions of plasma detected on liquid and solid food surfaces. Although several reviews focus on the inactivation mechanisms of plasma (Moisan et al., 2001; Boudam et al., 2006; Gaunt et al., 2006; Moreau et al., 2008), the inactivation mechanism 
and its potential regarding mild food surface decontamination is up to now not fully understood because the inactivation effects are depending on the applied plasma sources and experimental conditions. The presence of free radicals, UV emitting species, and charged particles is associated with the antimicrobial effect of the plasma (Laroussi, 2002; Moisan et al., 2002). Proposed inactivation effects are summarized by Schlüter and Fröhling (2014).

Detailed knowledge of inactivation effects is required for successful implementation of inactivation treatments in the production chain. Furthermore, the success of the inactivation process has to be verified online to ensure product safety. Due to the short shelf-life of fresh produce the results need to be obtained within a limited time period to enable contaminationrelated process control. Conventional microbiological techniques such as plate count methods are very time consuming and an absence of culturability cannot be directly related to cellular death because the bacteria can still be metabolically active (Bunthof and Abee, 2002). Therefore, the implementation of these methods in the processing chain is limited. In response to these limitations minimal duration methods to monitor inactivation treatments are required. Flow cytometry is a promising tool in food microbiology as it enables measurements on a single cell level and the detection of physiological property changes of bacteria after certain treatment processes within a short time due to the development of appropriate fluorescent dyes and improvement of optic technology. Fluorescent dye technology offers probes for a variety of cellular functions (Joux and Lebaron, 2000; Johnson et al., 2013). The use of fluorescent dye mixtures enables the classification into three types of viable cells: metabolically active, intact, or permeabilized cells (Hewitt and Nebe-VonCaron, 2004). The types of fluorescent dyes primary used in flow cytometry are: (i) fluorescent immune-conjugates and probes for fluorescence in situ hybridization; (ii) nucleic acid strains; and (iii) physiological probes to measure ions, membrane potential, enzymatic activity, viability, organelles, phagocytosis, cell development, and other cell properties (Haugland, 1994). The potential of flow cytometry to assess yeast cultures in food and beverage processing (e.g., bakery, wine industry, beer industry) is already shown (Herrero et al., 2006) as well as used to monitor the solid-state fermentation of basidiomycetes (Steudler et al., 2015). Flow cytometry is used in various studies to monitor bacterial inactivation (Luscher et al., 2004; Ananta et al., 2005; Berney et al., 2007; Mathys et al., 2007; Ananta and Knorr, 2009; Da Silveira and Abee, 2009; Joyce et al., 2011; Schenk et al., 2011; Fröhling et al., 2012b; Tamburini et al., 2013; Bigoni et al., 2014).

In this study, flow cytometry is used to investigate inactivation effects of peracetic acid, ozonated water, and cold atmospheric pressure plasma and to prove the ability of flow cytometric techniques for short-time monitoring of inactivation processes. For this purpose morphological and physiological properties of bacteria (membrane integrity and RNA/DNA damage, esterase activity, and membrane potential) were determined by flow cytometry. Various bacteria associated with food contamination are selected in order to examine the inactivation effects on different types of microorganisms. Listeria innocua (Gram-positive) is chosen as indicator strain for the human pathogenic Listeria monocytogenes (Kamat and Nair, 1996), a non-pathogenic Escherichia coli (Gram-negative) strain is chosen as representative for fecal contamination, and the plant pathogenic strain Pectobacterium carotovorum (Gram-negative) is chosen as a spoilage bacterium.

\section{Material and Methods}

\section{Cultivation of Bacteria}

Listeria innocua (DSM 20649), Escherichia coli (DSM 1116), and Pectobacterium carotovorum spp. carotovorum (DSM 30168) were stored as glass bead cultures at $-80^{\circ} \mathrm{C}$ for long-term maintenance. One glass bead was given to $5 \mathrm{ml}$ nutrient broth (Carl Roth GmbH \& Co KG, Germany) and incubated for $24 \mathrm{~h}$ without shaking at $37^{\circ} \mathrm{C}$ (L. innocua, E. coli) or $30^{\circ} \mathrm{C}$ (P. carotovorum) to re-activate the bacteria. Afterwards, $100 \mathrm{ml}$ nutrient broth was inoculated with bacteria suspension at a calculated optical density at $620 \mathrm{~nm}\left(\mathrm{OD}_{620}\right)$ of $0.07 \mathrm{ml}^{-1}$. Bacteria were harvested in the early to mid-stationary growth phase (L. innocua and E. coli: $18 \mathrm{~h}$ at $37^{\circ} \mathrm{C}$ or P. carotovorum: $18 \mathrm{~h}$ at $30^{\circ} \mathrm{C}$ ) by centrifugation at $3220 \times g$ for $15 \mathrm{~min}$ at $4^{\circ} \mathrm{C}$. The pelleted material was suspended in $50 \mathrm{mM}$ phosphate buffered saline (PBS) to a cell concentration of approximately 9-10 log CFU ml $\mathrm{ml}^{-1}$. PBS was prepared of $137 \mathrm{mM} \mathrm{NaCl}, 2.7 \mathrm{mM} \mathrm{KCl}$, $40.6 \mathrm{mM} \mathrm{Na}_{2} \mathrm{HPO}_{4}$, and $7.1 \mathrm{mM} \mathrm{KH}_{2} \mathrm{PO}_{4}$. The $\mathrm{pH}$ was adjusted to 7.0 with $\mathrm{HCl}$ and finally filtered with a $0.2 \mu \mathrm{m}$ membrane filter. All reagents were provided by Carl Roth GmbH \& Co KG, Germany.

\section{Treatment with Peracetic Acid}

Wofasteril ${ }^{\circledR}$ E400 (Kesla, Germany) was used as peracetic acid solution (PAA). Immediately before the treatments PAA concentration of $0.25 \%$ was prepared using tap water and tempered to $10^{\circ} \mathrm{C}$ in a water bath. The treatment volume was $10 \mathrm{ml}$ temperate PAA solution with an initial bacterial count of approximately $7 \log \mathrm{CFU} \mathrm{ml}{ }^{-1}$. The treatment times were $0.25,0.5,0.75,1,1.5$, and $2 \mathrm{~min}$. To stop the reaction after the defined treatment times the solution was added to $30 \mathrm{ml} 50 \mathrm{mM}$ PBS containing $0.6 \mathrm{M}$ sodium thiosulfate $\left(\mathrm{Na}_{2} \mathrm{~S}_{2} \mathrm{O}_{3}\right)$ and mixed for $10 \mathrm{~s}$. As a control bacteria were treated with tempered tab water. After treatment the samples were centrifuged at $3220 \times$ $g$ for $15 \mathrm{~min}$ at $4^{\circ} \mathrm{C}$ and afterwards the pelleted material was re-suspended in $10 \mathrm{ml} 50 \mathrm{mM}$ PBS for analyses of inactivation effects. It was also tested, whether $\mathrm{Na}_{2} \mathrm{~S}_{2} \mathrm{O}_{3}$ also lead to an inactivation of bacteria. For that, $10 \mathrm{ml}$ bacteria solution was added to $30 \mathrm{ml}$ PBS buffer containing $0.6 \mathrm{M} \mathrm{Na}_{2} \mathrm{~S}_{2} \mathrm{O}_{3}$. Effects of $\mathrm{Na}_{2} \mathrm{~S}_{2} \mathrm{O}_{3}$ on bacteria were detected by plate count method and were not significant. Each treatment was performed in triplicate.

\section{Treatment with Ozonated Water}

A Bewazon 1 ozone generator (BWT Wassertechnik GmbH, Germany) was used to generate ozonated water. The ozone concentration in $\mathrm{mg} \mathrm{l}^{-1}$ was measured in the spectrophotometer DR2800 (Hach Lange, Germany) using the LCK310 Chlorine/Ozone cuvette test (Hach Lange, Germany) following the instructions of the producer. Ozonated water with an ozone concentration of $3.8 \pm 1.4 \mathrm{mg} \mathrm{l}^{-1}$ was used 
for inactivation treatments. The treatment volume was $10 \mathrm{ml}$ ozonated water with an initial bacterial count of approximately $7 \log \mathrm{CFU} \mathrm{ml} \mathrm{ml}^{-1}$. The treatment time was set to $0.17,0.5,1$, 1.5 , and $2 \mathrm{~min}$. To stop the reaction the sample tubes were intensively shaken for approximately $30 \mathrm{~s}\left[\mathrm{O}_{3}(-)\right]$. To prove an inappropriate removal of residual ozone and to avoid false positive inactivation of bacteria, $\mathrm{Na}_{2} \mathrm{~S}_{2} \mathrm{O}_{3}$ was used to stop the reaction in a second trial. Therefore, the bacteria were treated with ozonated water using an ozone concentration of $3.8 \pm 1.02 \mathrm{mg} \mathrm{l}^{-1}$ as described above and the reaction was stopped with $\mathrm{Na}_{2} \mathrm{~S}_{2} \mathrm{O}_{3}\left[\mathrm{O}_{3}(+)\right]$. After the defined treatment time $44.1 \mathrm{mM} \mathrm{Na} 2 \mathrm{~S}_{2} \mathrm{O}_{3}$ was added to the sample tubes and the tubes were shaken for 2-3s to allow a homogenous distribution of $\mathrm{Na}_{2} \mathrm{~S}_{2} \mathrm{O}_{3}$ within the sample. An inactivation effect of $\mathrm{Na}_{2} \mathrm{~S}_{2} \mathrm{O}_{3}$ was excluded in preliminary experiments. After treatment the samples were centrifuged at $3220 \times g$ for $15 \mathrm{~min}$ at $4^{\circ} \mathrm{C}$ and afterwards the pelleted material was re-suspended in $50 \mathrm{mM}$ PBS for analyses of inactivation effects. Each treatment was performed in triplicate.

\section{Treatment with Cold Atmospheric Pressure Plasma}

The used plasma source and sample preparation is described in detail by Fröhling et al. (2012a). The distribution of reactive species was previously determined for a similar CAPP jet using Optical Emission Spectroscopy (Brandenburg et al., 2007). The initial bacterial concentration of each gel disc was approximately

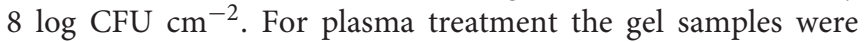
placed in the center of a glass sample holder and treated between 0.25 and $4 \mathrm{~min}$. The operating power of the plasma jet was set to $20 \mathrm{~W}$. The distance between the nozzle and the sample was $10 \mathrm{~mm}$ so that the plasma covered the inoculated region completely. The temperature of the samples during plasma treatment was recorded using a thermography camera (SC500, Flir Systems GmbH, Germany). As control inoculated gel sample were handled as described but without plasma treatment. Each treatment was performed in triplicate. Treated and untreated gel samples were transferred into sample tubes, and stored over night at $4^{\circ} \mathrm{C}$ before analysis due to logistic reasons. Effects of overnight storage on the obtained results were excluded in preliminary tests. To re-suspend the bacteria, $1 \mathrm{ml}$ PBS ( $50 \mathrm{mM}, \mathrm{pH} 7)$ were added to each sample tube and agitated for $5 \mathrm{~min}$ at $750 \mathrm{rpm}$ and $37^{\circ} \mathrm{C}$. The obtained bacteria suspension was transferred to sample tubes for plate count analysis and flow cytometric sample preparation.

\section{Flow Cytometric Analysis}

All experiments were performed using a Cytomics FC 500 flow cytometer (Beckman Coulter, Germany) equipped with a $20 \mathrm{~mW}$ argon ion laser emitting at a wavelength of $488 \mathrm{~nm}$. The fluorescence of thiazole orange, carboxyfluorescein, and green $\mathrm{DiOC}_{2}(3)$ was collected in the FL1 photomultiplier with a band pass filter of $525 \pm 25 \mathrm{~nm}$ and the fluorescence of propidium iodide and red $\mathrm{DiOC}_{2}(3)$ was recorded in the FL3 photomultiplier with a short pass filter of $620 \mathrm{~nm}$. Fluorescence compensation was performed to correct the overlap of one dye's emission into another dye's detector. The parameters were collected as logarithmic signals and the obtained data were analyzed using CXP Analysis software (Beckman Coulter, Germany). Ten thousand events were measured at a flow rate of approximately 300 events $\mathrm{s}^{-1}$. Unless otherwise stated, the density plots obtained by flow cytometric analyses were divided into four regions. The regions represent cells with different physiological properties. The average of the percentage values obtained from three density plots was calculated and illustrated as kinetics in diagrams where the $\mathrm{x}$-coordinate displays the treatment time and the $y$-coordinate the percentage of stained cells.

\section{Membrane Potential}

3,3'-diethyloxacarbocyanine iodide $\left[\operatorname{DiOC}_{2}(3)\right]$ was applied to measure the membrane potential of bacteria cells. The staining was performed according to Novo et al. (1999) with small modifications. $\mathrm{DiOC}_{2}(3)$ was provided by Sigma-Aldrich, Germany. For staining with $\mathrm{DiOC}_{2}(3)$ the bacteria suspension was diluted in $50 \mathrm{mM}$ PBS containing $20 \mathrm{mM} \mathrm{D}$-glucose to achieve a cell concentration of approximately $6 \log$ cells $\mathrm{ml}^{-1}$. Then, $30 \mu \mathrm{M} \mathrm{DiOC} 2(3)$ was added and incubated for $15 \mathrm{~min}$ in the dark at room temperature. Afterwards the suspension was centrifuged at $4000 \times g$ and $4^{\circ} \mathrm{C}$ for $6 \mathrm{~min}$ (Gram-negative bacteria) or $12,000 \times g$ for $10 \mathrm{~min}$ at $4^{\circ} \mathrm{C}$ (Gram-positive bacteria). The pelleted material was re-suspended in $50 \mathrm{mM}$ PBS to a cell density of approximately 6 log cells per $\mathrm{ml}$ and immediately measured in the flow cytometer.

Cells were completely depolarized with carbonyl cyanide m-chlorophenylhydrazone to set the parameters of the flow cytometer. The settings of the FL1 [green $\mathrm{DiOC}_{2}(3)$-fluorescence intensity] and FL3 [red $\mathrm{DiOC}_{2}(3)$-fluorescence intensity] photomultiplier were chosen so that the mean fluorescence of green and red DiOC2(3) was detected in the same channel. The ratio of mean red to mean green DiOC2(3)-fluorescence channel value was calculated to investigate changes in the membrane potential. Due to the chosen cytometer settings the red/green DiOC2(3)-fluorescence ratio of depolarized cells was $\leq 1$. It was assumed that the red/green ratio of untreated cells represents the relative membrane potential of intact cells (Novo et al., 1999). A reduction of the red/green ratio stands for the loss cell membrane potential.

\section{Membrane Integrity and RNA/DNA Damage}

Thiazole orange (TO) and Propidium iodide (PI) were used to distinguish between RNA and DNA in bacteria cells as well as to indicate compromised cell membranes and DNA damage. Therefore, $0.42 \mu \mathrm{M}$ TO and $30 \mu \mathrm{M}$ PI were added to a bacteria suspension containing $\sim 6 \mathrm{log}$ cells $\mathrm{ml}^{-1}$ and incubated for $10 \mathrm{~min}$ at room temperature in the dark before flow cytometric measurements. Due to the fact that the TO-RNA-complex shows lower fluorescence intensities than the TO-DNA-complex (Nygren et al., 1998) the mean value of TO-fluorescence intensity was used to distinguish between RNA and DNA staining.

\section{Esterase Activity and Membrane Permeabilization}

The bacteria suspension was centrifuged at $4000 \times g$ and $4^{\circ} \mathrm{C}$ for $6 \mathrm{~min}$ (Gram-negative bacteria) or $12,000 \times g$ for $10 \mathrm{~min}$ 
at $4{ }^{\circ} \mathrm{C}$ (Gram-positive bacteria) after inactivation treatment. The pelleted material was re-suspended in PBS $(50 \mathrm{mM}, \mathrm{pH} 7)$ to obtain a calculated $\mathrm{OD}_{620}$ of approximately 10 for staining procedure. Fifty micromole cFDA (Gram-positive bacteria) or $0.83 \mathrm{mM}$ cFDA (Gram-negative bacteria) was added to the bacterial suspension in the sample tubes and allowed to penetrate into the cells for $15 \mathrm{~min}$ (Gram-positive bacteria) or $45 \mathrm{~min}$ (Gram-negative bacteria) in a water bath set to $37^{\circ} \mathrm{C}$. Afterwards, surplus cFDA was removed by centrifugation for 6 min at $4000 \times$ $g$ and $4^{\circ} \mathrm{C}$ or $12,000 \times g$ for $10 \mathrm{~min}$ at $4^{\circ} \mathrm{C}$. The pelleted material was re-suspended in $50 \mathrm{mM}$ PBS to obtain a cell concentration of approximately $6 \log$ cells $\mathrm{ml}^{-1}$. To investigate membrane integrity of bacteria cells $30 \mu \mathrm{M}$ propidium iodide was added to cFDA treated cells and allowed to penetrate into permeabilized cells for $10 \mathrm{~min}$ at $4^{\circ} \mathrm{C}$ in the dark before flow cytometric measurements.

\section{Total Viable Cell Count}

The viable cell count of bacteria after inactivation treatments was determined by traditional culture methods in duplicate. Therefore, the samples were serially diluted in Rotilabo ${ }^{\circledR}$. microtest plates (96er U-profile, Carl Roth $\mathrm{GmbH} \&$ Co KG, Germany) using $50 \mathrm{mM}$ PBS as dilution solution. $100 \mu \mathrm{l}$ of each dilution was spread on the cultivation medium. The number of colony forming units (CFU) was evaluated after $48 \mathrm{~h}$ at $37^{\circ} \mathrm{C}(\mathrm{L}$. innocua, Standard-I agar: Carl Roth GmbH \& Co KG, Germany); $48 \mathrm{~h}$ at $30^{\circ} \mathrm{C}$ (P. carotovorum, MacConkey agar: Carl Roth $\mathrm{GmbH}$ \& Co KG, Germany); or $24 \mathrm{~h}$ at $37^{\circ} \mathrm{C}$ (E. coli, Standard-I agar: Carl Roth GmbH \& Co KG, Germany). The detection limit of plate count analyses was $1 \log \mathrm{CFU} \mathrm{ml} \mathrm{m}^{-1}$ for treatment with peracetic acid and ozonated water and $1 \log \mathrm{CFU} \mathrm{cm}{ }^{-2}$ for treatment with cold atmospheric pressure plasma.

\section{Mathematical Modeling and Statistical Analysis}

To obtain an inactivation kinetic for each treatment parameter, the average of six values of colony forming units were calculated (three independent experiments analyzed in duplicate). The inactivation kinetics obtained were modeled with the log-linear regression model with tailing using GInaFiT (Geeraerd and Van Impe Inactivation Model Fitting Tool), a freeware Add-in for Microsoft ${ }^{\circledR}$ Excel (Geeraerd et al., 2005).

The GInaFiT tool was also applied to the obtained flow cytometric data. The relative membrane potential was modeled with the log-linear regression model with tailing; esterase activity and the decrease of intact cells were described by the log-linear regression. Additionally, membrane permeabilization kinetics were modeled with a Gompertz model using the software SigmaPlot13 (Systat Software Inc.).

Statistical analyses to evaluate significant difference between the data were performed using Origin ${ }^{\circledR} 7.5$ software. One WayANOVA with Tukey test and a significance level of 0.05 were used.

\section{Results}

\section{Treatment Effects on Total Viable Count}

For all tested bacteria the peracetic acid treatment was applied at $10^{\circ} \mathrm{C}$ and the temperature of the ozonated water was approximately $12^{\circ} \mathrm{C}$. Temperature measurements at $20 \mathrm{~W}$ CAPP showed that the average temperature of the gel discs slightly increased to approximately $27^{\circ} \mathrm{C}$ (data not shown).

The initial count of E. coli for PAA treatment was $7.72 \log$ CFU ml ${ }^{-1}$. The treatment with $0.25 \%$ PAA decreased the viable count to the detection limit of $1 \log \mathrm{CFU} \mathrm{m}{ }^{-1}$ within $0.25 \mathrm{~min}$ treatment time. With increasing treatment time to $0.5,0.75$, and $1 \mathrm{~min}$ the total viable count was between 1.37 and $1.98 \mathrm{CFU} \mathrm{ml}^{-1}$ and decreased again to the detection limit after 1.5 and $2 \mathrm{~min}$ treatment time (Figure 1A). For treatment with ozonated water the initial count of E. coli was 7.71 and $7.54 \log \mathrm{CFU} \mathrm{m}{ }^{-1}$. The treatment with an ozone concentration of $3.8 \mathrm{mg} \mathrm{l}^{-1} \mathrm{O}_{3}(-)$ led to a reduction of bacteria to the detection limit of $1 \log \mathrm{CFU} \mathrm{ml} \mathrm{m}^{-1}$ after a treatment time of $0.17 \mathrm{~min}$ (Figure 1A). Using an ozone concentration of $3.78 \mathrm{mg}^{-1} \mathrm{O}_{3}(+)$ led to a decrease of total viable count to $3.58 \log \mathrm{CFU} \mathrm{ml}{ }^{-1}$ within $2 \mathrm{~min}$ (Figure 1A). For CAPP treatment the initial load of E. coli was $8.66 \log \mathrm{CFU} \mathrm{cm} \mathrm{cm}^{-2}$. Within $4 \mathrm{~min}$ the total viable count of E. coli was reduced to 6.22 $\log \mathrm{CFU} \mathrm{\textrm {cm } ^ { - 2 }}$ (Figure 1A).

$6.02 \log \mathrm{CFU} \mathrm{m} \mathrm{m}^{-1}$ was used as initial count of $P$. carotovorum for the treatment with $0.25 \%$ PAA. The total viable count of $P$. carotovorum was decreased to the detection limit of $1 \log$ CFU ml $\mathrm{m}^{-1}$ within $0.5 \mathrm{~min}$ treatment time (Figure 1B). Using ozonated water at a concentration of $2.8 \mathrm{mg} \mathrm{l}^{-1} \mathrm{O}_{3}(-)$, the total viable count of $P$. carotovorum was reduced from $7.6 \mathrm{log}$ $\mathrm{CFU} \mathrm{ml} \mathrm{m}^{-1}$ to the detection limit of $1 \log \mathrm{CFU} \mathrm{ml} \mathrm{m}^{-1}$ within 0.17 min (Figure 1B). Within 2 min the total viable count of $P$. carotovorum was only reduced from 6.74 to $3.15 \log \mathrm{CFU} \mathrm{m} \mathrm{m}^{-1}$ using an ozone concentration of $3.82 \mathrm{mg} \mathrm{l}^{-1} \mathrm{O}_{3}(+)$ (Figure 1B). The treatment with CAPP reduced the total viable count of $P$. carotovorum from $7.79 \log \mathrm{CFU} \mathrm{cm}^{-2}$ to the detection limit of $1 \log \mathrm{CFU} \mathrm{cm} \mathrm{cm}^{-2}$ within $1.5 \mathrm{~min}$ (Figure 1B).

The initial count of L. innocua for treatment with $0.25 \%$ PAA was $7.09 \log \mathrm{CFU} \mathrm{ml} \mathrm{m}^{-1}$. Within $0.75 \mathrm{~min}$ the total viable count of L. innocua was reduced to the detection limit of $1 \log \mathrm{CFU} \mathrm{m}{ }^{-1}$ but increased again to 5.36 and $5.20 \log \mathrm{CFU} \mathrm{m} \mathrm{m}^{-1}$ after 1.5 and $2 \mathrm{~min}$, respectively (Figure 1C). The initial count of $7.65 \mathrm{CFU}$ $\mathrm{ml}^{-1}$ was reduced to $1.08 \log \mathrm{CFU} \mathrm{ml} \mathrm{m}^{-1}$ with $2 \mathrm{~min}$ treatment with ozonated water and an ozone concentration of $3.42 \mathrm{mg} \mathrm{l}^{-1}$ $\mathrm{O}_{3}(-)$. The total viable count of $L$. innocua was only reduced from 7.79 to $3.81 \log \mathrm{CFU} \mathrm{m}{ }^{-1}$ within 2 min using $3.8 \mathrm{mg} \mathrm{l}^{-1}$ $\mathrm{O}_{3}(+)$ (Figure 1C). The treatment with CAPP led to a microbial reduction from $8.63 \log \mathrm{CFU} \mathrm{cm} \mathrm{cm}^{-2}$ to the detection limit of $1 \log$ $\mathrm{CFU} \mathrm{cm} \mathrm{cm}^{-2}$ within $1.25 \mathrm{~min}$ (Figure 1C).

\section{Effects of Treatments on Membrane Potential}

The measurement of relative membrane potential using $\mathrm{DiOC}_{2}(3)$ showed that the untreated $E$. coli cells had a red/green ratio of 8.8 before treatment with $0.25 \%$ PAA. After PAA treatment the red/green ratio was reduced to approximately 1.0 regardless of the treatment time indicating a reduced membrane potential (Figure 2A). The relative membrane potential of $E$. coli was also immediately reduced from 7.5 to approximately 1 using ozonated water with an ozone concentration of $3.8 \mathrm{mg} \mathrm{l}^{-1} \mathrm{O}_{3}(-)$ (Figure 2A). However, using the same ozone concentration but stopping the reaction with $\mathrm{Na}_{2} \mathrm{~S}_{2} \mathrm{O}_{3}\left[\mathrm{O}_{3}(+)\right]$ only decreased the relative membrane potential from 8.4 to approximately 2 indicating a higher relative membrane potential of E. coli 

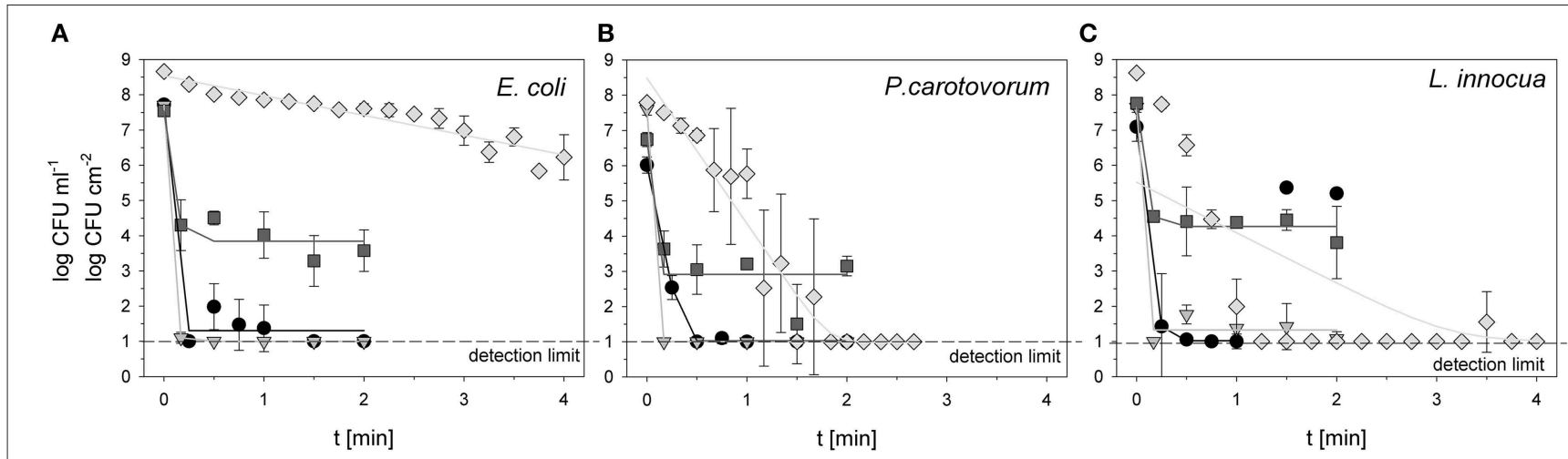

FIGURE 1 | Total viable count of $E$. coli (A), P. carotovorum (B), and $L$. innocua (C) after PAA treatment (circles: $10^{\circ} \mathrm{C}, 0.25 \%$ PAA), CAPP treatment (rhombus: $20 \mathrm{~W}$ ), and treatment with ozonated water [triangle: $3.8 \pm 1.02 \mathrm{mg} \mathrm{I}^{-1} \mathrm{O}_{3}(-)$; square: $3.8 \pm 1.02 \mathrm{mg} \mathrm{I}^{-1} \mathrm{O}_{3}(+)$ ]. The lines represent the inactivation obtained by the GlnaFit tool.

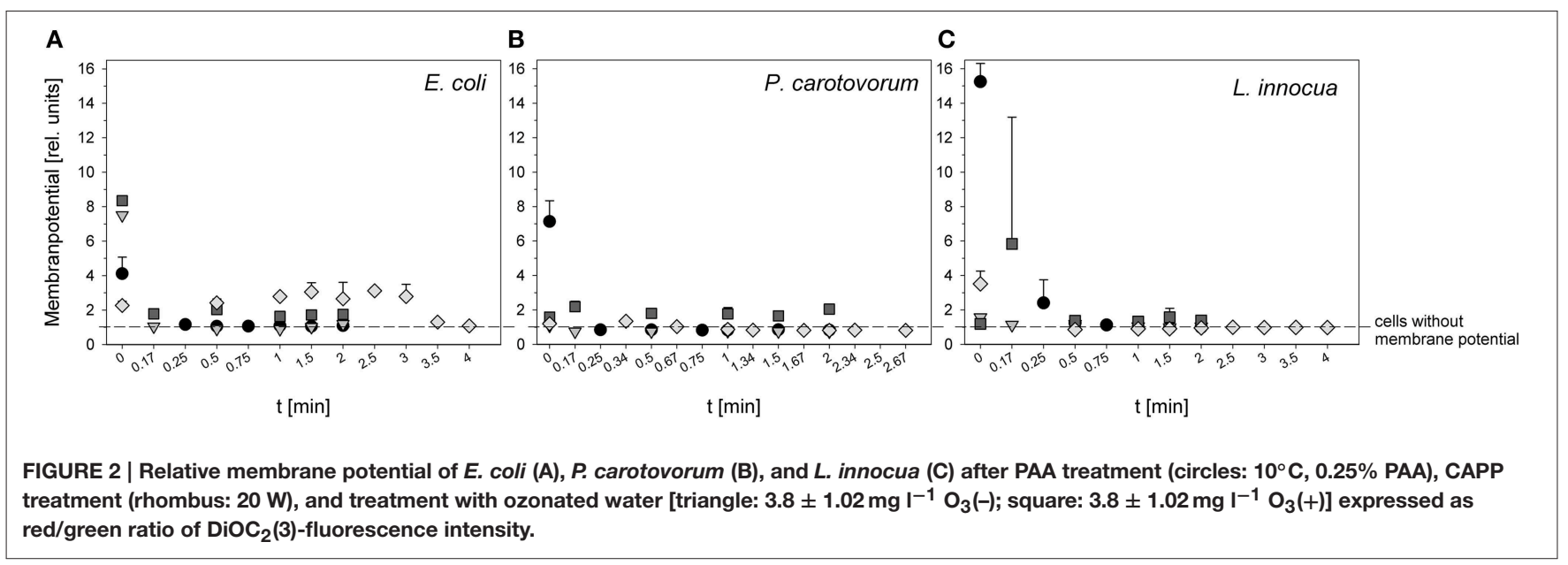

cells than after PAA treatment and ozone treatment where the reaction is stopped by shaking (Figure $\mathbf{2 A}$ ). The initial value of the relative membrane potential of $E$. coli cells was approximately 2 before plasma treatment and remained almost constant after treatment with CAPP regardless of the treatment time. Only after 3 min treatment time a reduction of membrane potential could be detected (Figure 2A).

The cells of $P$. carotovorum were immediately depolarized from 7.13 to $<1$ after treatment with $0.25 \%$ PAA regardless of treatment time (Figure 2B). P. carotovorum cells after treatment were also depolarized after treatment with $2.8 \mathrm{mg} \mathrm{l}^{-1} \mathrm{O}_{3}(-)$. However, the initial relative membrane potential was only 1.08 and was reduced to $<1$ after $0.17 \mathrm{~min}$ (Figure 2B). A slightly higher relative membrane potential (1.58) was detected before treatment with $3.82 \mathrm{mg} \mathrm{l}^{-1} \mathrm{O}_{3}(+)$ but the relative membrane potential remained almost constant during 2 min treatment (Figure 2B). The treatment with CAPP reduced the relative membrane potential from 1.2 to $<1$ within 1 min treatment (Figure 2B).

L. innocua cells had a relative membrane potential of 15.25 before treatment with $0.25 \%$ PAA. The cells were completely depolarized after 1 min treatment (Figure 2C). Using ozonated water with an ozone concentration of $3.42 \mathrm{mg} \mathrm{l}^{-1} \mathrm{O}_{3}(-)$ reduced the relative membrane potential from 1.57 to $<1$ within $1.5 \mathrm{~min}$ (Figure 2C). In contrast, $3.8 \mathrm{mg} \mathrm{l}^{-1} \mathrm{O}_{3}(+)$ increased the relative membrane potential from 1.19 to 5.82 within $0.17 \mathrm{~min}$ and with increasing treatment time the relative membrane potential decreased again to approximately 1.5 and remained almost constant during treatment up to 2 min (Figure 2C). The relative membrane potential of $L$. innocua cells was immediately reduced from 3.51 to $<1$ within 1 min treatment with CAPP (Figure 2C).

\section{Treatment Effects on Membrane Integrity and Bacterial RNA and DNA}

During treatment with $0.25 \%$ PAA the percentage of permeabilized E. coli cells increased to $10 \%$ within $2 \mathrm{~min}$ and the percentage of slightly permeabilized cells increased to $88.6 \%$. The percentage of intact cells decreased to $0 \%$ within $2 \mathrm{~min}$ and the population of unstained cells/cell fragments remained below 3\% within the treatment time (Figure 3A). During $0.25 \%$ PAA treatment the mean TO-fluorescence 

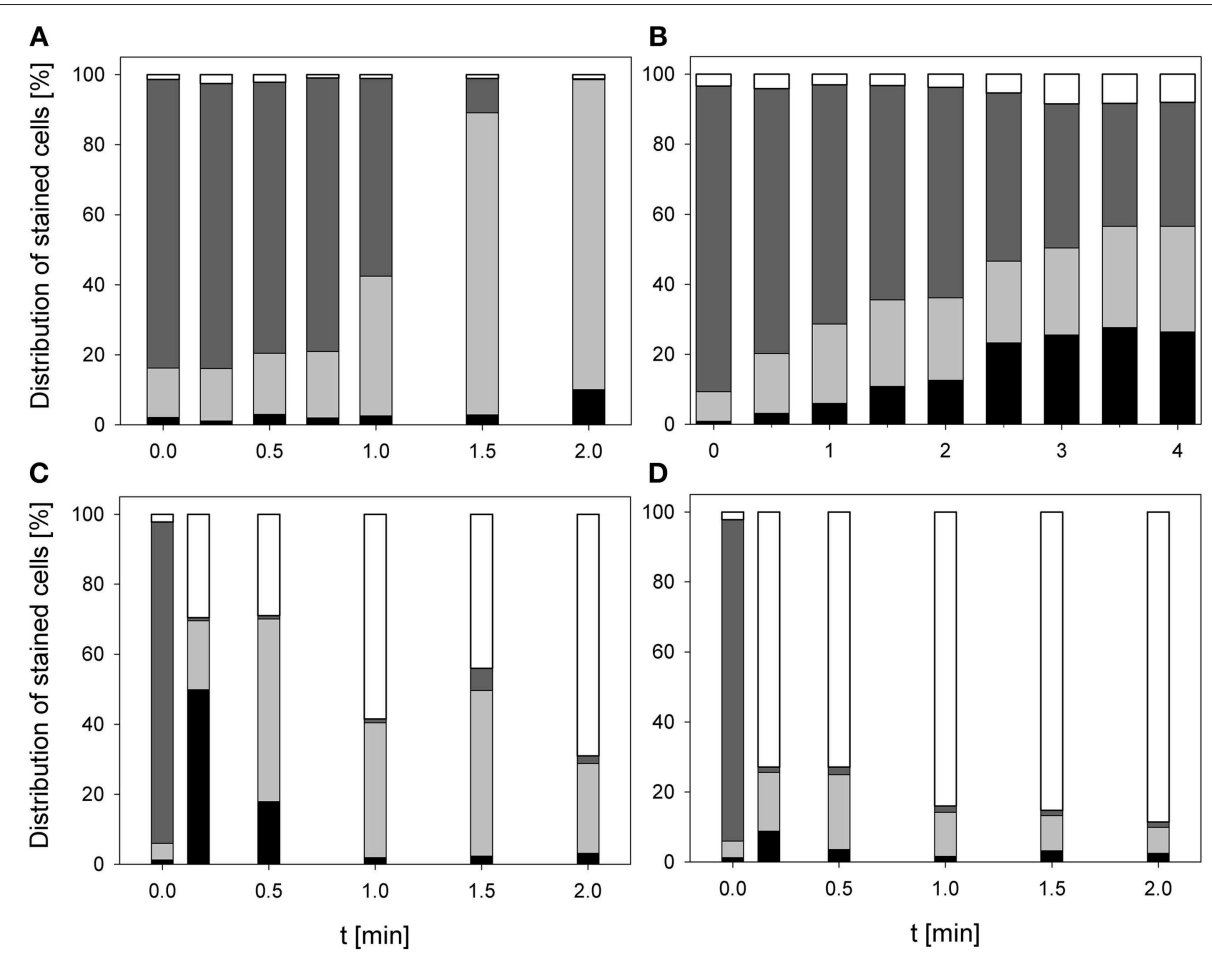

FIGURE 3 | Membrane integrity of $E$. coli after PAA treatment [(A) $10^{\circ} \mathrm{C}, 0.25 \%$ PAA], CAPP treatment [(B) 20 W), and treatment with ozonated water [(C) $3.8 \mathrm{mg} \mathrm{I}^{-1} \mathrm{O}_{3}(-)$; (D) $3.78 \mathrm{mg} \mathrm{I}^{-1} \mathrm{O}_{3}(+)$ ]. Black bars representing permeabilized cells; gray bars representing slightly permeabilized cells, light gray bar representing intact cells, and white bars representing cells without fluorescence/cell fragments.

intensity significantly increased within the first $0.5 \mathrm{~min}$ and then significantly decreased again with increasing treatment time (Table 1). The treatment with CAPP led to an increase of permeabilized E. coli cells to approximately $27 \%$ within $4 \mathrm{~min}$. The percentage of slightly permeabilized cells also continuously increased to $30 \%$ within 4 min whereas the percentage of intact cells simultaneously decreased to $35 \%$. The population of unstained cells/cell fragments remained almost constant at approximately $3-4 \%$ within the first 2 treatment minutes. A further increase of treatment time led to an increase of unstained cells/cell fragments to approximately 8\% (Figure 3B). During treatment with CAPP the mean TO-fluorescence intensity significantly increased in the first $0.5 \mathrm{~min}$ and then remained almost constant with increasing treatment time (Table 1). $3.78 \mathrm{mg} \mathrm{l}^{-1} \mathrm{O}_{3}(-)$ led to an increase of permeabilized E. coli cells to $49.8 \%$ within $0.17 \mathrm{~min}$ and with increasing treatment time up to $2 \mathrm{~min}$ the percentage of permeabilized cells decreased again to $3.1 \%$. Concurrently, the percentage of intact cells decreased immediately to $<1 \%$ within $0.17 \mathrm{~min}$ and remained almost constant at this level. However, after $1.5 \mathrm{~min}$ ozone treatment the percentage of intact cells increased again to $6.3 \%$ and decreased to $2.2 \%$ after $2 \mathrm{~min}$. The percentage of slightly permeabilized cells increased within $0.5 \mathrm{~min}$ of treatment to $52.3 \%$ and decreased again with increasing treatment time to $25.6 \%$ (Figure 3C). The treatment with $3.8 \mathrm{mg} \mathrm{l}^{-1} \mathrm{O}_{3}(+)$ only slightly increased the percentage of permeabilized E. coli cells to $8.3 \%$ within $0.17 \mathrm{~min}$ and with increasing treatment time the percentage decreased again to $2.5 \%$. The number of slightly permeabilized cells increased to $21.4 \%$ within $0.5 \mathrm{~min}$ and decreased again to $7.4 \%$ with increasing treatment time. The applied ozone concentration led to an immediate decrease of intact cells to $<2 \%$ within $0.17 \mathrm{~min}$ whereas the population of unstained cells/cell fragments immediately increased to $72.9 \%$ within $0.17 \mathrm{~min}$ and continuously increased to $88.6 \%$ applying treatment times up to $2 \mathrm{~min}$ (Figure 3D). E. coli showed a significant decrease of mean TO-fluorescence intensity after both applied ozone treatments (Table 1).

The treatment with $0.25 \%$ PAA led to a continuous increase of permeabilized P. carotovorum cells to $91.5 \%$ within $2 \mathrm{~min}$ of treatment. The percentage of slightly permeabilized cells increased to $56.5 \%$ within $1 \mathrm{~min}$ of treatment and decreased again to $8.1 \%$ after $1.5 \mathrm{~min}$. The number of intact cells decreased during 2 min treatment with PAA to $0.1 \%$ and the population of unstained cells/cell fragments remained almost constant $<2 \%$ during the PAA treatment time of $2 \mathrm{~min}$ (Figure 4A). During $0.25 \%$ PAA treatment the mean TO-fluorescence intensity significantly increased in the first $0.25 \mathrm{~min}$ and then significantly decreased again with increasing treatment time (Table 2). The percentage of permeabilized $P$. carotovorum cells continuously increased during $2.67 \mathrm{~min}$ treatment with CAPP to $86.7 \%$ whereas the percentage of intact cells simultaneously decreased to $0.9 \%$. Within the first $0.67 \mathrm{~min}$ of treatment, the percentage of unstained cells/cell fragments increased to $14.5 \%$ and decreased 
TABLE 1 | Mean TO-fluorescence intensity of $E$. coli after different treatments.

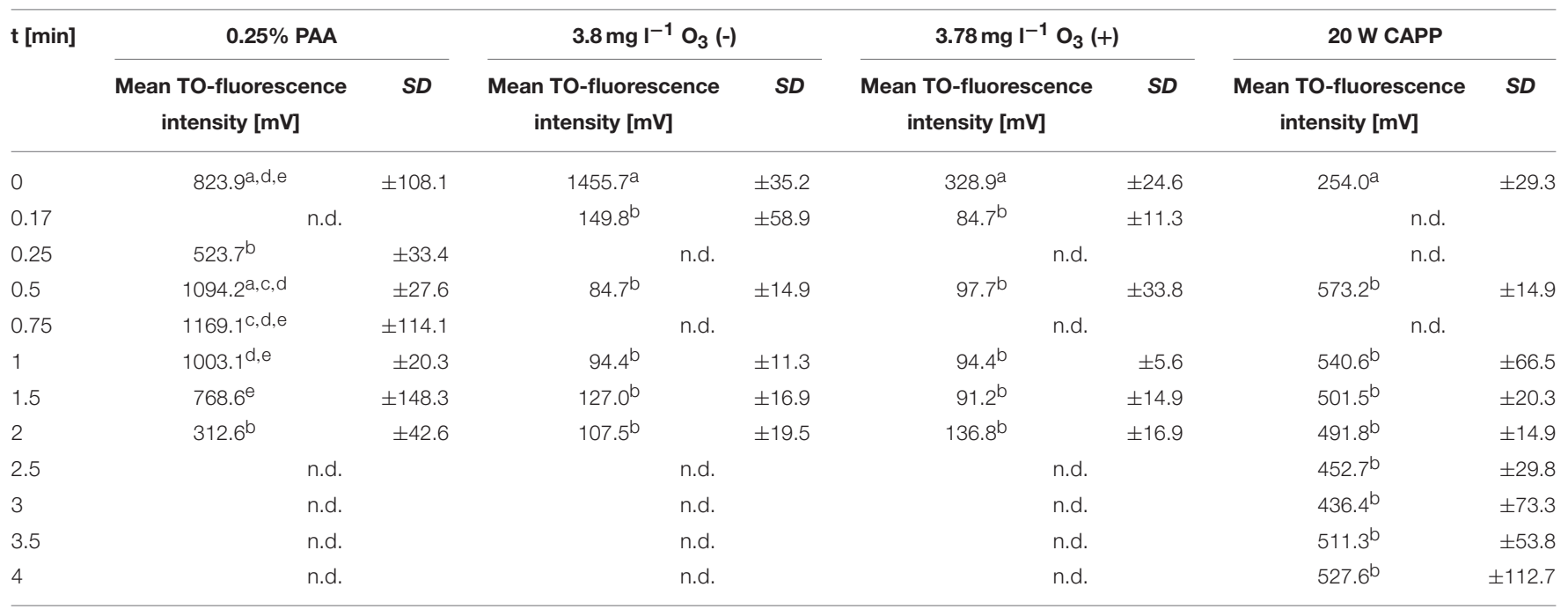

$S D$, Standard deviation of three independent experiments.

${ }^{a-e}$ Different letters within the lines indicate significant differences at a significance level of 0.05 .

again with increasing treatment time to $0.9 \%$. The population of slightly permeabilized cells increased to $25.5 \%$ within the first $1.34 \mathrm{~min}$ and decreased again with increasing treatment time (Figure 4B). The mean TO-fluorescence intensity of $P$. carotovorum did not significantly increase within the first treatment minute but with increasing treatment time to $2 \mathrm{~min}$ the mean TO-fluorescence intensity significantly increased. A further increase of treatment time led to a significant reduction of mean TO-fluorescence intensity (Table 2). At $2.8 \mathrm{mg} \mathrm{l}^{-1} \mathrm{O}_{3}(-$ ) the percentage of permeabilized $P$. carotovorum cells increased to $82.4 \%$ within $0.5 \mathrm{~min}$ and decreased again with increasing treatment time to $69.6 \%$. The number of slightly permeabilized cells decreased within the first $0.5 \mathrm{~min}$ to approximately $2 \%$ but increased again to $8-9 \%$ after $2 \mathrm{~min}$. The percentage of intact cells was immediately reduced to $<1 \%$ within $0.17 \mathrm{~min}$ but increased again to $4-9 \%$ within the next $1.5 \mathrm{~min}$ of treatment. The population of unstained cells/cell fragments increased to approximately $17 \%$ within $0.17 \mathrm{~min}$ and remained almost constant at this level with increasing treatment time to $2 \mathrm{~min}$ (Figure 4C). The mean TO-fluorescence intensity did not significantly increase during treatment with $2.8 \mathrm{mg} \mathrm{l}^{-1} \mathrm{O}_{3}(-)$ (Table 2). Using $3.82 \mathrm{mg} \mathrm{l}^{-1} \mathrm{O}_{3}(+)$ led only to a minor increase of permeabilized $P$. carotovorum cells. The percentage of intact cells decreased within $0.5 \mathrm{~min}$ from 91 to $5.4 \%$, increased again to $26.1 \%$ after $1 \mathrm{~min}$ and decreased again to $3.9 \%$ after $2 \mathrm{~min}$. The population of unstained cells/cell fragments continuously increased during treatment with $3.82 \mathrm{mg} \mathrm{l}^{-1} \mathrm{O}_{3}(+)$ to $85.1 \%$ with the exception of $1 \mathrm{~min}$ where a decrease to $62.9 \%$ was observed. The percentage of slightly permeabilized $P$. carotovorum cells increased up to $18.1 \%$ within $0.17 \mathrm{~min}$ but decreased again with increasing treatment time to approximately $9 \%$ (Figure 4D). Mean TO-fluorescence intensity of $P$. carotovorum showed no significant changes after ozone treatment (Table 2).
The treatment with $0.25 \%$ PAA did only slightly increase the percentage of permeabilized L. innocua cells within the first treatment minute. Increasing the treatment time to $2 \mathrm{~min}$ the number of permeabilized cells was reduced again from 8.8 to $4.1 \%$. The percentage of slightly permeabilized cells was reduced to $4-7 \%$ within the first treatment minutes but with increasing treatment time it continuously increased to approximately $15 \%$. The population of intact cells remained almost constant during the treatment with $0.25 \%$ PAA with the exception of a treatment time of $1 \mathrm{~min}$ where only $6.1 \%$ intact cells were detected and $70.7 \%$ of the cells remained unstained. With this exception the population of unstained cells/cell fragments remained almost constant below $2 \%$ during the treatment (Figure 5A). The mean TO-fluorescence intensity of $L$. innocua significantly decreased after $0.75 \mathrm{~min}$ and no further significant changes were observed with increasing treatment time (Table 3). The percentage of permeabilized L. innocua cells increased to $61.0 \%$ during $4 \mathrm{~min}$ treatment with CAPP. Concurrently, the number of slightly permeabilized L. innocua cells increased to approximately $20 \%$ within $0.5 \mathrm{~min}$ and remained almost constant within the next 3.5 treatment minutes. The percentage of intact cells continuously decreased to $4.0 \%$ during CAPP treatment and the number of unstained cells/cell fragments increased to approximately $37 \%$ within the first $2.5 \mathrm{~min}$ and decreased again to approximately $20 \%$ within the next $1.5 \mathrm{~min}$ (Figure 5B). The mean TOfluorescence intensity significantly increased due to the CAPP treatment (Table 3). The treatment with $3.42 \mathrm{mg} \mathrm{l}^{-1} \mathrm{O}_{3}(-)$ led to an increase of permeabilized L. innocua cells to $75.7 \%$ within $0.17 \mathrm{~min}$ and decreased again with increasing treatment time to $47.8 \%$ whereas the percentage of slightly permeabilized cells and the population of intact cells immediately decreased to $<1 \%$ within $0.17 \mathrm{~min}$ and remained constant at this level during the residual treatment time. The population of unstained cells/cell fragments continuously increased to $50.9 \%$ during 

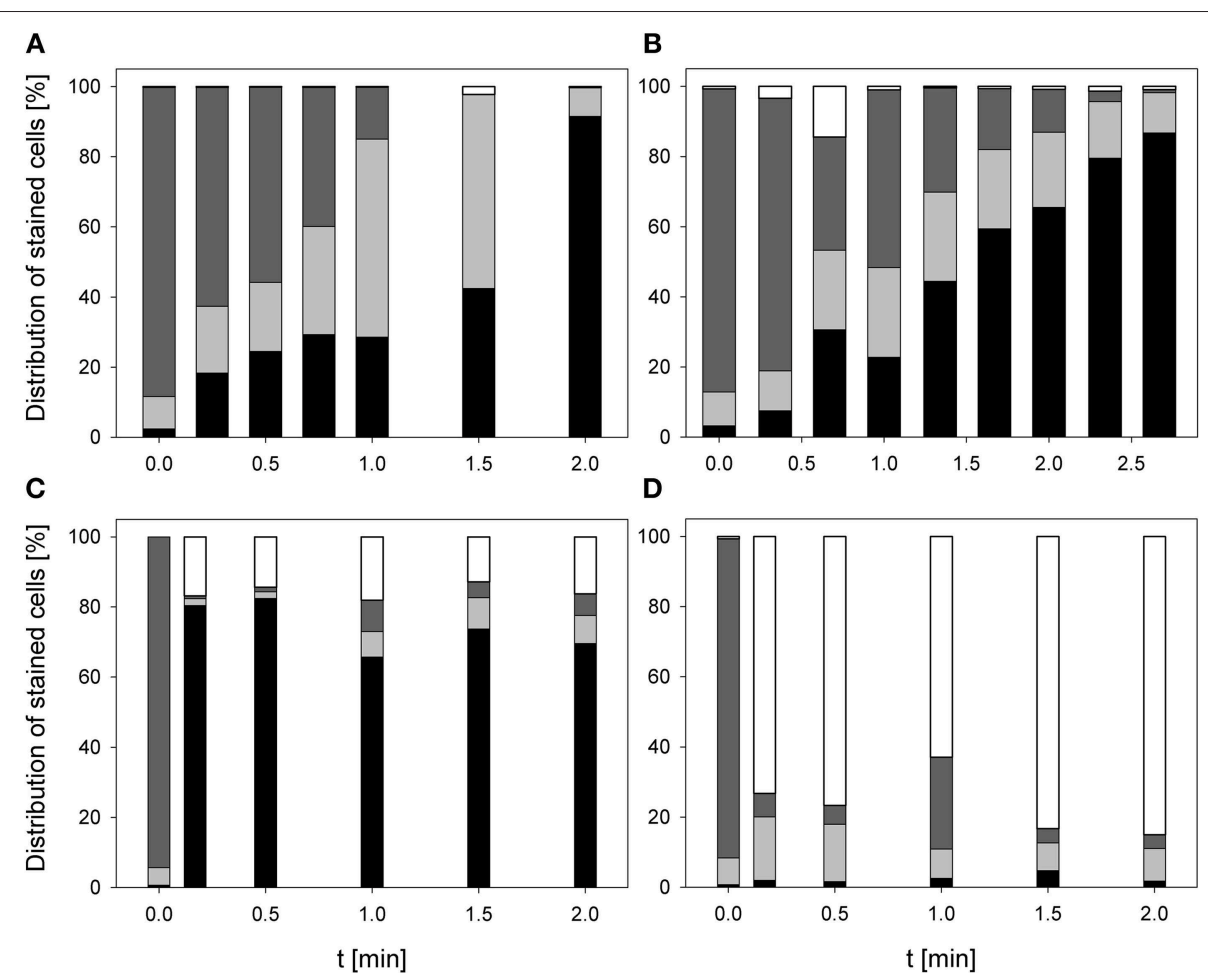

FIGURE 4 | Membrane integrity of $P$. carotovorum after PAA treatment [(A) $10^{\circ} \mathrm{C}, 0.25 \%$ PAA], CAPP treatment [(B) 20 W], and treatment with ozonated water [(C) $2.8 \mathrm{mg} \mathrm{I}^{-1} \mathrm{O}_{3}(-)$; (D) $\mathbf{3 . 8} \mathrm{mg} \mathrm{I}^{-1} \mathrm{O}_{3}(+)$ ]. Black bars representing permeabilized cells; gray bars representing slightly permeabilized cells, light gray bar representing intact cells, and white bars representing cells without fluorescence/cell fragments.

ozone treatment (Figure 5C). In contrast, the population with permeabilized cells only slightly increased to approximately $99 \%$ within $0.5 \mathrm{~min}$ treatment with $3.8 \mathrm{mg} \mathrm{l}^{-1} \mathrm{O}_{3}(+)$ and remained almost constant at this level during the remaining treatment time. The percentage of slightly permeabilized cells and the percentage of intact cells decreased immediately to $<2 \%$ and remained at this level up to $2 \mathrm{~min}$. The population of unstained cells/cell fragment continuously increased to $80-90 \%$ within $2 \mathrm{~min}$ (Figure 5D). L. innocua showed a significant decrease of mean TO-fluorescence intensity after both applied ozone treatments (Table 3).

\section{Impact on Esterase Activity and Membrane Permeabilization}

The treatment with $0.25 \%$ PAA led to an increase of permeabilized $E$. coli cells without esterase activity from 2.4 to $68.3 \%$ within $2 \mathrm{~min}$ treatment. Concurrently, intact $E$. coli cells with esterase activity decreased from 86.7 to $0 \%$. Permeabilized cells with esterase activity increased from 6.5 to $81.2 \%$ within the first treatment minute and decreased again to $30 \%$ in the next treatment minute. The percentage of unstained cells/cell fragments remained constant $<5 \%$ during treatment time (Figure 6A). The treatment with CAPP increased the permeabilized E. coli cells with esterase activity to $23.3 \%$ within the first treatment minute and remained almost constant during the next 3 treatment minutes. Simultaneously, the percentage of intact cells with esterase activity decreased within $1.5 \mathrm{~min}$ treatment and remained almost constant at approximately 50\% during the next $2.5 \mathrm{~min}$. The percentage of permeabilized cells with esterase activity was continuously increasing during treatment whereas the percentage of unstained cells/cell fragment was continuously decreasing (Figure 6B). The number of permeabilized $E$. coli cells without esterase activity increased from 0.9 to $60.3 \%$ within $0.17 \mathrm{~min}$ treatment with $3.8 \mathrm{mg} \mathrm{l}^{-1}$ $\mathrm{O}_{3}(-)$ and decreased again to $7.0 \%$ with increasing treatment time to $2 \mathrm{~min}$. Concurrently, the percentage of intact cells with esterase activity decreased from 91.3 to $6.0 \%$ within $0.5 \mathrm{~min}$ and increased again to $23.1 \%$ in the next $1.5 \mathrm{~min}$. Permeabilized cells with esterase activity increased from 6.4 to $46.4 \%$ within $1 \mathrm{~min}$ treatment and decreased again to $36.1 \%$ within the next treatment minute. The percentage of unstained cells/cell fragments is continuously increasing to $33.8 \%$ during treatment time of $2 \mathrm{~min}$ (Figure 6C). Similar results were obtained for the treatment with $3.8 \mathrm{mg} \mathrm{l}^{-1} \mathrm{O}_{3}(+)$ (Figure 6D). However, the percentage of unstained cells/cell fragments increased to $83.1 \%$ within $2 \mathrm{~min}$ and the percentage of intact cells with esterase activity immediately decreased to $<1 \%$ within $0.17 \mathrm{~min}$.

During $2 \mathrm{~min}$ treatment with $0.25 \%$ PAA the percentage of permeabilized $P$. carotovorum cells without esterase activity continuously increased from $6.6 \%$ to approximately $99.2 \%$. Simultaneously, the number of intact cells with esterase activity decreased from 66.7 to $0 \%$ and the percentage of unstained cells/cell fragments remained constant between 0 and $3 \%$. The percentage of permeabilized cells with esterase activity increased 
TABLE 2 | Mean TO-fluorescence intensity of $P$. carotovorum after different treatments.

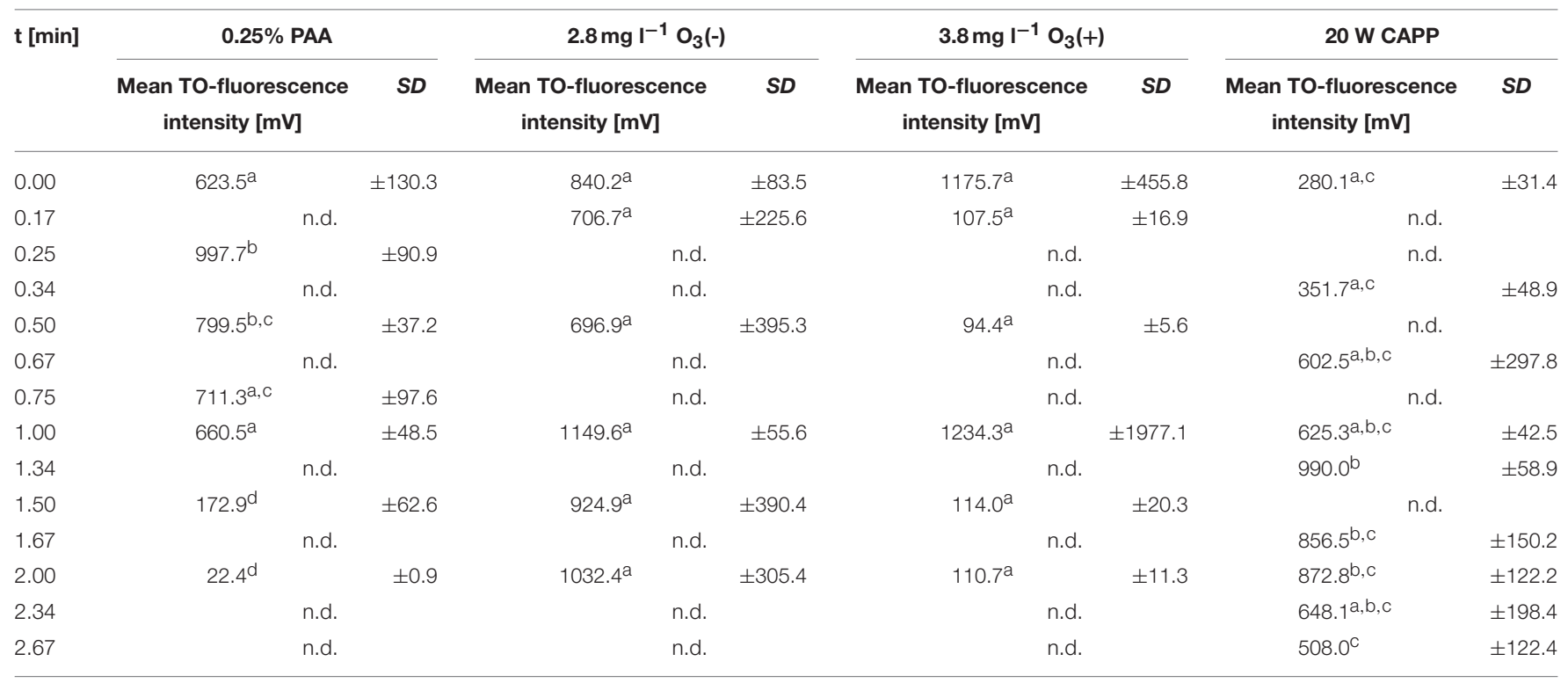

$S D$, Standard deviation of three independent experiments.

${ }^{a-d}$ Different letters within the lines indicate significant differences at a significance level of 0.05 .

within the first $0.25 \mathrm{~min}$ treatment from 23.8 to $47.4 \%$ and subsequently decreased again with increasing treatment time reaching a value below 1\% (Figure 7A). The percentage of permeabilized $P$. carotovorum cells without esterase activity is continuously increasing from 7.1 to $98.0 \%$ during treatment with CAPP for $2.67 \mathrm{~min}$ and the percentage of intact cells with esterase activity decreased at the same time from 81.5 to $0.1 \%$. The number of permeabilized cells with esterase activity remained almost constant within the first minute and decreased with increasing treatment time. The percentage of unstained cells/cell fragments increased in the first $0.67 \mathrm{~min}$ of treatment to approximately $10 \%$ and decreased to $0.5 \%$ with increasing treatment time (Figure 7B). Using an ozone concentration of $2.8 \mathrm{mg} \mathrm{l}^{-1} \mathrm{O}_{3}(-)$ increased the percentage of permeabilized cells without esterase activity from 2.8 to $81.4 \%$ within $0.17 \mathrm{~min}$ and with increasing treatment time the percentage of permeabilized cells without esterase activity remained almost constant. Concurrently, the number of intact cells with esterase activity decreased from 91.2 to $<1 \%$ within $0.17 \mathrm{~min}$. The percentage of permeabilized cells with esterase activity remained almost constant during the ozone treatment below 3.5\%. The population of unstained cells/cell fragments increased within 0.17 min to approximately $20 \%$ and remained almost constant with increasing treatment time (Figure 7C). In contrast, the percentage of permeabilized $P$. carotovorum cells without esterase activity increased from 15.2 to $20 \%$ within 0.17 min treatment with $3.8 \mathrm{mg} \mathrm{l}^{-1} \mathrm{O}_{3}(+)$ and decreased again to approximately $10 \%$ with increasing treatment time to $0.5 \mathrm{~min}$ and remained almost constant at this level during the next $1.5 \mathrm{~min}$ (Figure 7D). The percentage of intact cells with esterase activity and permeabilized cells with esterase activity immediately decreased from 49.1 to $<1 \%$ and from $21.1 \%$ to $<1 \%$, respectively, and remained constant at this level. Simultaneously, the percentage of unstained cells/cell fragments increased to $85-90 \%$ within $0.17 \mathrm{~min}$ and remained almost constant at this level with increasing treatment time.

The number of permeabilized L. innocua cells without esterase activity only slightly increased to $8.8 \%$ during treatment with $0.25 \%$ PAA for $2 \mathrm{~min}$. The percentage of permeabilized cells with esterase activity remained almost constant at around $10 \%$ within the first treatment minute and then increased to $23.3 \%$ within the next treatment minute. Concurrently, the percentage of intact cells with esterase activity slightly decreased from 86.6 to $66.9 \%$ within $2 \mathrm{~min}$ and the percentage of unstained cells/cell fragments remained almost constant at approximately $1 \%$ (Figure 8A). The treatment with CAPP led to an increase of permeabilized $L$. innocua cells without esterase activity from 0.1 to $74.9 \%$ and simultaneously, the percentage of intact cells with esterase activity decreased from 97.5 to $0.6 \%$. The percentage of permeabilized cells with esterase activity increased within the first 2 treatment minutes from 2.3 to $27.4 \%$ and decreased again to $5.3 \%$ within the next 2 treatment minutes. The number of unstained cells/cell fragments was continuously increasing to approximately 20\% (Figure 8B). Using an ozone concentration of $3.42 \mathrm{mg} \mathrm{l}^{-1} \mathrm{O}_{3}(-)$ increased the percentage of permeabilized $L$. innocua cells with esterase activity immediately within $0.17 \mathrm{~min}$ from 1.7 to $81.5 \%$ but with increasing treatment time the percentage decreased again to $59.3 \%$. The percentage of permeabilized cells with esterase activity as well as the percentage of intact cells with esterase activity were also immediately reduced from 48.7 to $0 \%$ and from 49.1 to $0 \%$, respectively, within $0.17 \mathrm{~min}$ but they remained constant at this level with increasing treatment time. Concurrently, the percentage of unstained cells/cell fragments continuously increased from 0.5 to $40.7 \%$ within $2 \mathrm{~min}$ (Figure $\mathbf{8 C}$ ). In contrast, the percentage of permeabilized L. innocua cells without esterase activity slightly 

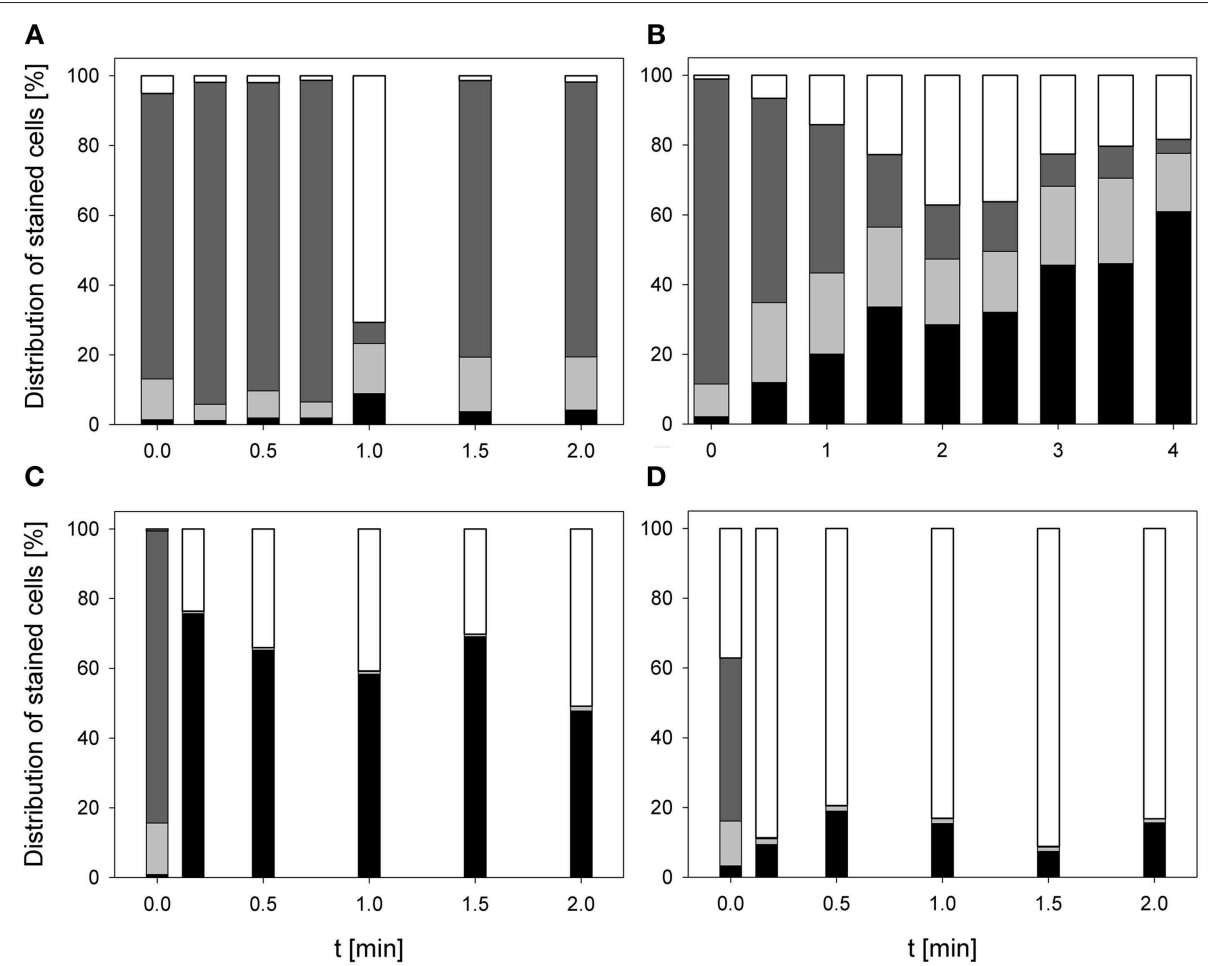

FIGURE 5 | Membrane integrity of $L$. innocua after PAA treatment [(A) $10^{\circ} \mathrm{C}, 0.25 \%$ PAA], CAPP treatment [(B) 20 W], and treatment with ozonated water [(C) $\mathbf{3 . 4 2} \mathrm{mg} \mathrm{I}^{-1} \mathrm{O}_{3}(-)$; (D) $\mathbf{3 . 8} \mathrm{mg} \mathrm{I}^{-1} \mathrm{O}_{3}(+)$ ]. Black bars representing permeabilized cells; gray bars representing slightly permeabilized cells, light gray bar representing intact cells, and white bars representing cells without fluorescence/cell fragments.

increased to approximately $20 \%$ during treatment with $3.8 \mathrm{mg} \mathrm{l}^{-1}$ $\mathrm{O}_{3}(+)$ regardless of the treatment time. While the percentage of permeabilized cells with esterase activity and the percentage of intact cells with esterase activity were immediately reduced to $0 \%$ within $0.17 \mathrm{~min}$, the percentage of unstained cells/cell fragments immediately increased to approximately 80\% (Figure 8D).

\section{Mathematical Modeling of Inactivation Kinetics and Flow Cytometric Data}

All inactivation kinetics were modeled with the log-linear regression model with tailing, the Gompertz model was used to describe the membrane permeabilization. The reduction of intact cells and the reduction of esterase activity followed a log-linear regression and the depolarization of the cells was modeled with the log-linear regression model with tailing.

Statistical measures and parameter values obtained from mathematical models fitted to the experimental data of inactivated E. coli are summarized in Table 4. Using $0.25 \%$ PAA at $10^{\circ} \mathrm{C}$ a $4 \log$ reduction of $E$. coli could be achieved within $\pm 0.08 \mathrm{~min}$ according to the applied model and the inactivation rate was $145.6 \mathrm{~min}^{-1}$. The depolarization rate of E. coli was $34.0 \mathrm{~min}^{-1}$. The reduction rate of intact cells was $6.4 \mathrm{~min}^{-1}$ and the esterase inactivation rate of PAA treated $E$. coli cells was $92.7 \mathrm{~min}^{-1}$. For the cell membrane permeabilization a rate of $0.2 \mathrm{~min}^{-1}$ was calculated. A $4 \log$ reduction of E. coli using $3.8 \mathrm{mg} \mathrm{l}^{-1} \mathrm{O}_{3}(-)$ was achieved within $\pm 0.1 \mathrm{~min}$ and the inactivation rate was $98.8 \mathrm{~min}^{-1}$. Depolarization of cells due to treatment with ozonated water was calculated with a rate of $101.5 \mathrm{~min}^{-1}$. The decrease rate of intact cells was $58.4 \mathrm{~min}^{-1}$ and the cell membrane permeabilization rate was $0.01 \mathrm{~min}^{-1}$. The inactivation of esterase activity occurred with a rate of $33.2 \mathrm{~min}^{-1}$. The inactivation rate of $E$. coli was $46.5 \mathrm{~min}^{-1}$, the depolarization rate was $220.8 \mathrm{~min}^{-1}$, the decrease rate of intact cells was $55.0 \mathrm{~min}^{-1}$ and the rate of esterase inactivation was $54.4 \mathrm{~min}^{-1}$ using $3.78 \mathrm{mg} \mathrm{l}^{-1} \mathrm{O}_{3}(+)$. The cell membrane permeabilization was calculated with a rate of $-0.02 \mathrm{~min}^{-1}$. The inactivation rate of $E$. coli after CAPP treatment was calculated as $1.3 \mathrm{~min}^{-1}$. The reduction of membrane potential could be achieved with a rate of $0.6 \mathrm{~min}^{-1}$. The decrease of intact cells was calculated with a rate of $60.5 \mathrm{~min}^{-1}$ while the inactivation rate of esterase was $9.4 \mathrm{~min}^{-1}$. Cell membrane permeabilization was calculated with a rate of $1.2 \mathrm{~min}^{-1}$.

Statistical measures and parameter values obtained from mathematical models fitted to the experimental data of inactivated $P$. carotovorum are summarized in Table 5. A 4 log reduction of total viable count of $P$. carotovorum using PAA was achieved within $\pm 0.3 \mathrm{~min}$ and the inactivation rate was $32.2 \mathrm{~min}^{-1}$. The membrane depolarization rate was $72.3 \mathrm{~min}^{-1}$ while the reduction of intact cells was calculated with a rate of $104.5 \mathrm{~min}^{-1}$. The esterase inactivation rate was $49.6 \mathrm{~min}^{-1}$ and the cell membrane permeabilization rate was $0.01 \mathrm{~min}^{-1}$. A $4 \log$ reduction of total viable count of $P$. carotovorum using $2.8 \mathrm{mg}$ $\mathrm{I}^{-1} \mathrm{O}_{3}(-)$ was achieved within $\pm 0.06 \mathrm{~min}$ and the inactivation rate was $155.1 \mathrm{~min}^{-1}$. The membrane depolarization rate was 
TABLE 3 | Mean TO-fluorescence intensity of $L$. innocua after different treatments.

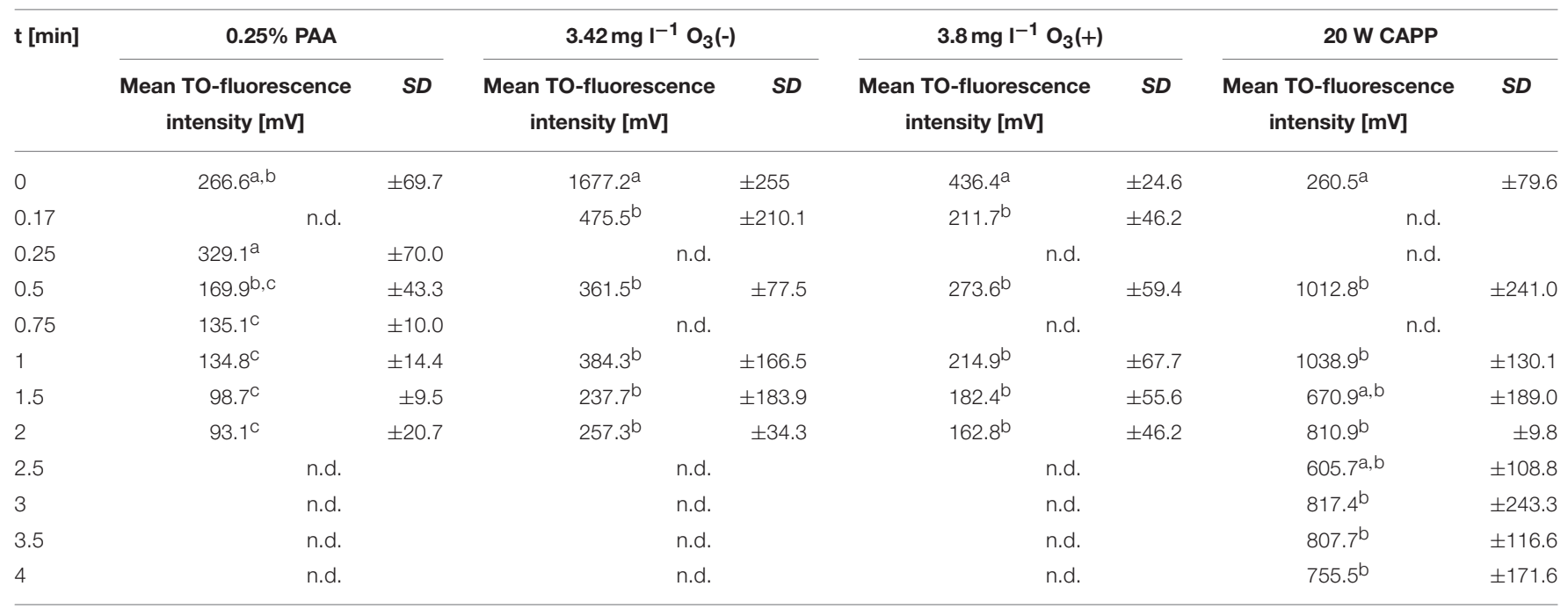

$S D$, Standard deviation of three independent experiments.

${ }^{a-c}$ Different letters within the lines indicate significant differences at a significance level of 0.05 .

$184.4 \mathrm{~min}^{-1}$, the decrease rate of intact cells was $53.3 \mathrm{~min}^{-1}$, and the esterase inactivation rate was $59.2 \mathrm{~min}^{-1}$. The cell membrane permeabilization was calculated with a rate of $0.05 \mathrm{~min}^{-1}$. The inactivation kinetic of $P$. carotovorum after treatment with $3.82 \mathrm{mg} \mathrm{l}^{-1} \mathrm{O}_{3}(+)$ showed a calculated inactivation rate of $42.86 \mathrm{~min}^{-1}$. The membrane depolarization could not be described with the log-linear regression model with tailing. The decrease rate of intact cells was $55.7 \mathrm{~min}^{-1}$. The esterase inactivation rate was $31.8 \mathrm{~min}^{-1}$ while the cell permeabilization rate was $-2.1 \mathrm{~min}^{-1}$. The microbial inactivation kinetic of $P$. carotovorum by CAPP showed a $4 \log$ reduction within \pm $1 \mathrm{~min}$ and the inactivation rate was $9.5 \mathrm{~min}^{-1}$. The membrane depolarization rate was $1.6 \mathrm{~min}^{-1}$, the reduction of esterase activity was $76.7 \mathrm{~min}^{-1}$, and the reduction rate of intact cells was $73.6 \mathrm{~min}^{-1}$. The cell membrane permeabilization was calculated with a rate of $0.4 \mathrm{~min}^{-1}$.

Statistical measures and parameter values obtained from mathematical models for experimental data of inactivated $L$. innocua are summarized in Table 6. The microbial inactivation of L. innocua after treatment with $0.25 \%$ PAA could not be described with the applied model because the total viable count increased again after 1 min treatment time. The depolarization rate was $118.5 \mathrm{~min}^{-1}$, the decrease rate of intact cells was $50.1 \mathrm{~min}^{-1}$, and esterase inactivation rate was $22.8 \mathrm{~min}^{-1}$. The cell membrane permeabilization rate was $0.2 \mathrm{~min}^{-1}$. A $4 \mathrm{log}$ reduction of total viable count of $L$. innocua after treatment with $3.42 \mathrm{mg} \mathrm{l}^{-1} \mathrm{O}_{3}(-)$ was achieved within \pm $0.06 \mathrm{~min}$ and the inactivation rate was $212.4 \mathrm{~min}^{-1}$. The loss of membrane potential was calculated with a rate of $14.3 \mathrm{~min}^{-1}$. The decrease rate of intact cells was $54.1 \mathrm{~min}^{-1}$ and the esterase inactivation rate was $31.7 \mathrm{~min}^{-1}$. Using $3.8 \mathrm{mg} \mathrm{l}^{-1} \mathrm{O}_{3}(+)$, the inactivation rate of $L$. innocua was $47.8 \mathrm{~min}^{-1}$, the cell membrane permeabilization and the membrane depolarization of L. innocua was calculated with a rate of -0.2 and $4.5 \mathrm{~min}^{-1}$, respectively. The decrease rate of intact cells was $30.2 \mathrm{~min}^{-1}$ and the inactivation rate of esterase was $17.3 \mathrm{~min}^{-1}$. The cell membrane permeabilization was calculated with a rate of $-0.20 \mathrm{~min}^{-1}$. Within $\pm 2.92 \mathrm{~min}$ a $4 \log$ reduction of total viable count of L. innocua could be realized by CAPP treatment and the inactivation rate was $3.3 \mathrm{~min}^{-1}$. The depolarization rate due to CAPP treatment was $57.6 \mathrm{~min}^{-1}$. The decrease of intact cells was calculated with a rate of $42.6 \mathrm{~min}^{-1}$ and the esterase inactivation rate was $48.6 \mathrm{~min}^{-1}$. The cell permeabilization was calculated with a rate of $0.5 \mathrm{~min}^{-1}$.

\section{Discussion}

It is assumed that PAA induces oxidation of proteins, enzymes, or other metabolites and acts on DNA bases (Kitis, 2004). In order to investigate the inactivation mechanism of PAA on bacteria flow cytometric analyses were performed. Although the flow cytometric analysis suggests that most bacteria cells were intact after 0.25 min PAA treatment only a small number of colony forming units were detectable by a plate count method. This implies cell permeabilization is not the cause of the loss of culturability and other mechanisms must induce this effect. Rossi et al. (2007) found a constant decrease in viable heterotrophic bacteria using SYBR Green I and PI. But the percentage of intact cells was about $50 \%$ even after 36 min PAA treatment. The percentage of damaged cells (double-stained cells with SYBR Green I + PI) remained constant during $5 \mathrm{mg} \mathrm{l}^{-1}$ PAA treatment. Similar results were obtained for total heterotrophic bacteria during $5 \mathrm{mg} \mathrm{l}^{-1}$ PAA treatment (Antonelli et al., 2006) and 15 and $25 \mathrm{mg} \mathrm{l}^{-1}$ PAA treatment (Mezzanotte et al., 2003). Increasing mean TO-fluorescence intensity of cells indicates that TO is bound to DNA and not to RNA (Nygren et al., 1998). The increase of mean TO-fluorescence intensity implies that RNA was damaged due to PAA treatment and TO was predominantly bound to DNA. The decrease of mean TO-fluorescence intensity with increasing treatment time can be explained by the increased 

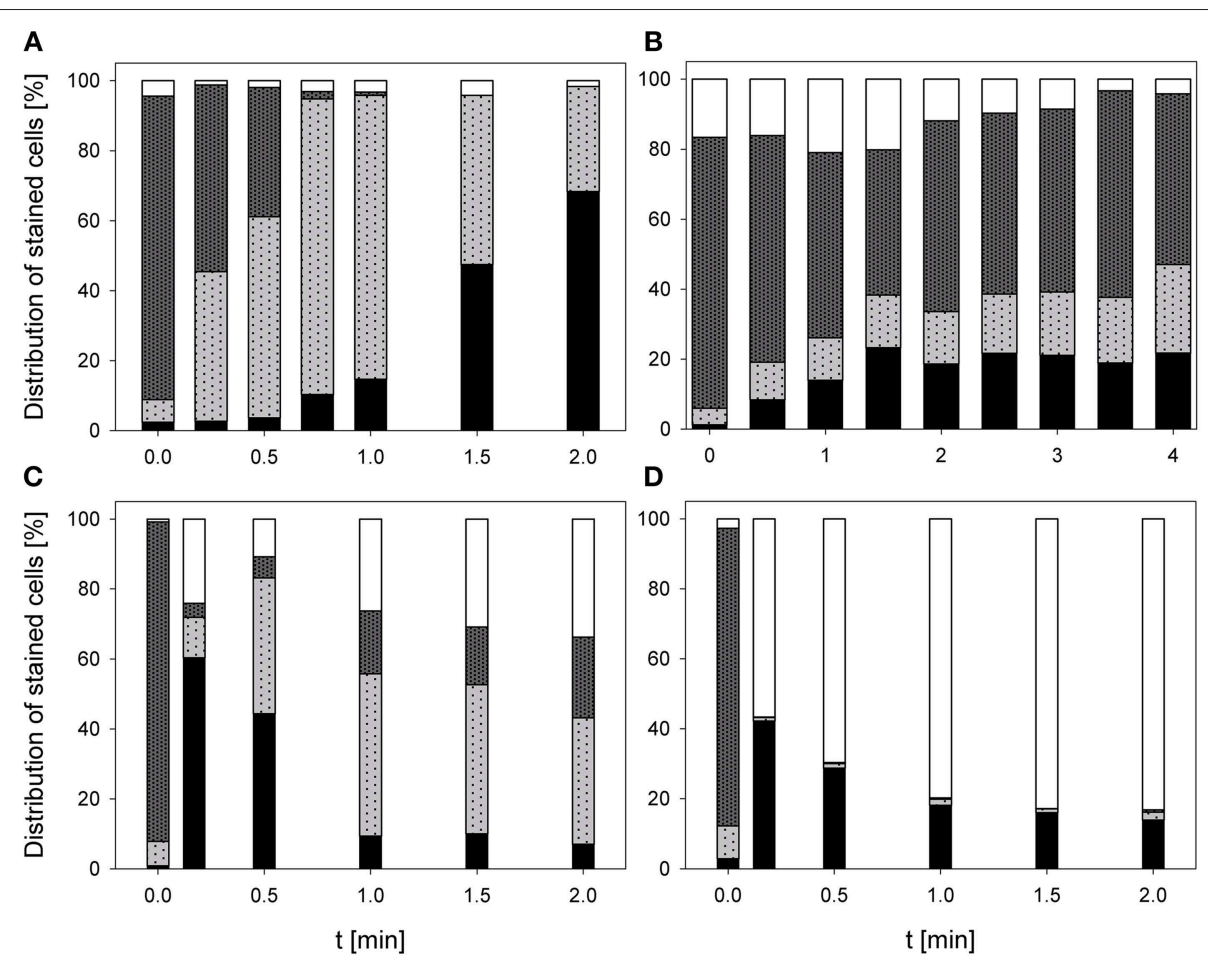

FIGURE 6 | Esterase activity and membrane integrity of $E$. coli after PAA treatment [(A) $10^{\circ} \mathrm{C}, 0.25 \%$ PAA], CAPP treatment [(B) 20 W], and treatment with ozonated water [(C) $3.8 \mathrm{mg} \mathrm{I}^{-1} \mathrm{O}_{3}(-)$; (D) $3.78 \mathrm{mg} \mathrm{I}^{-1} \mathrm{O}_{3}(+)$ ]. Black bars representing permeabilized cells without esterase activity; dotted gray bars representing permeabilized cells with esterase activity, dotted light gray bar representing intact cells with esterase activity, and white bars representing cells without fluorescence/cell fragments.

amount of PI in the cells that quenched the TO-fluorescence. The loss of culturability after 0.25 min PAA treatment at different temperatures is evidently not related to cell death. According to Bunthof (2002) the physiological status of cells can be classified in four states with culturability as highest form of physiological fitness. Nevertheless, the cells that lost culturability might be able to recover and subsequently cause disease. After PAA treatment the red/green $\mathrm{DiOC}_{2}(3)$ ratio was reduced to approximately 1.0 indicating a reduced membrane potential of all tested bacteria. However, E. coli cells are not completely depolarized because red/green ratio of completely depolarized cells is below one. The membrane potential is involved in numerous processes of bacterial physiology and is strongly related to bacterial viability (Novo et al., 1999). The measurement of a low membrane potential after PAA treatment supports the assumption that the cells may still cause diseases. Cells still showed esterase activity after PAA treatment, this indicates that the cells still have metabolic activity but according to the plate count results these cells were no longer culturable. Increasing treatment times showed lower cF-fluorescence intensity as untreated bacteria cells. This indicates that a lower amount of cFDA was hydrolyzed after PAA treatment which may be related to a lower amount of active esterase within the cells. This may be a result of an oxidation of enzymes by PAA (Kitis, 2004). Park et al. (2014) found a higher reduction of Enterococcus faecium using $5 \mathrm{ppm}$ PAA measured by plate count than by the ATP bioluminescence method. They suggested that the bacteria are injured due to the PAA treatment but they are still viable. Modeling of changes in bacterial physiological properties measured by flow cytometry after PAA treatment may help to determine the most sensitive target sites of bacteria to PAA.

The inactivation of bacteria by ozone is attributed to changes in cell permeability and cell lyses (Moore et al., 2000) which can elicit the changes in scatter intensities. Consequently, the membrane integrity of bacteria cells after ozone treatment was investigated. Ozone leads to a rupture of cells and cell lyses with subsequent attack on nucleic acids and enzymes (Pascual et al., 2007). The low fluorescence intensity of TO can be related to unbound dye adherent to cell fragments and the occurrence of PI-fluorescence indicates that this cell population did not show cell lyses. The unstained fraction indicates that the cells are highly permeabilized so that cell lyses occurred and therefore, no fluorescence could be detected. It can also be assumed that nucleic acids are affected by the ozone and therefore, an intercalating of fluorescent dyes with DNA and RNA was not possible. A complete destruction of bacteria in drinking water after ozonation was observed using SYBR Green I and propidium iodide. Along with a few detectable bacteria cells a high amount of cell debris was detected with the flow cytometer after ozonation of drinking water (Hammes et al., 2008). Similar results were obtained for bacteria cells from ozonated river water after staining with SYBR Green and PI. The 

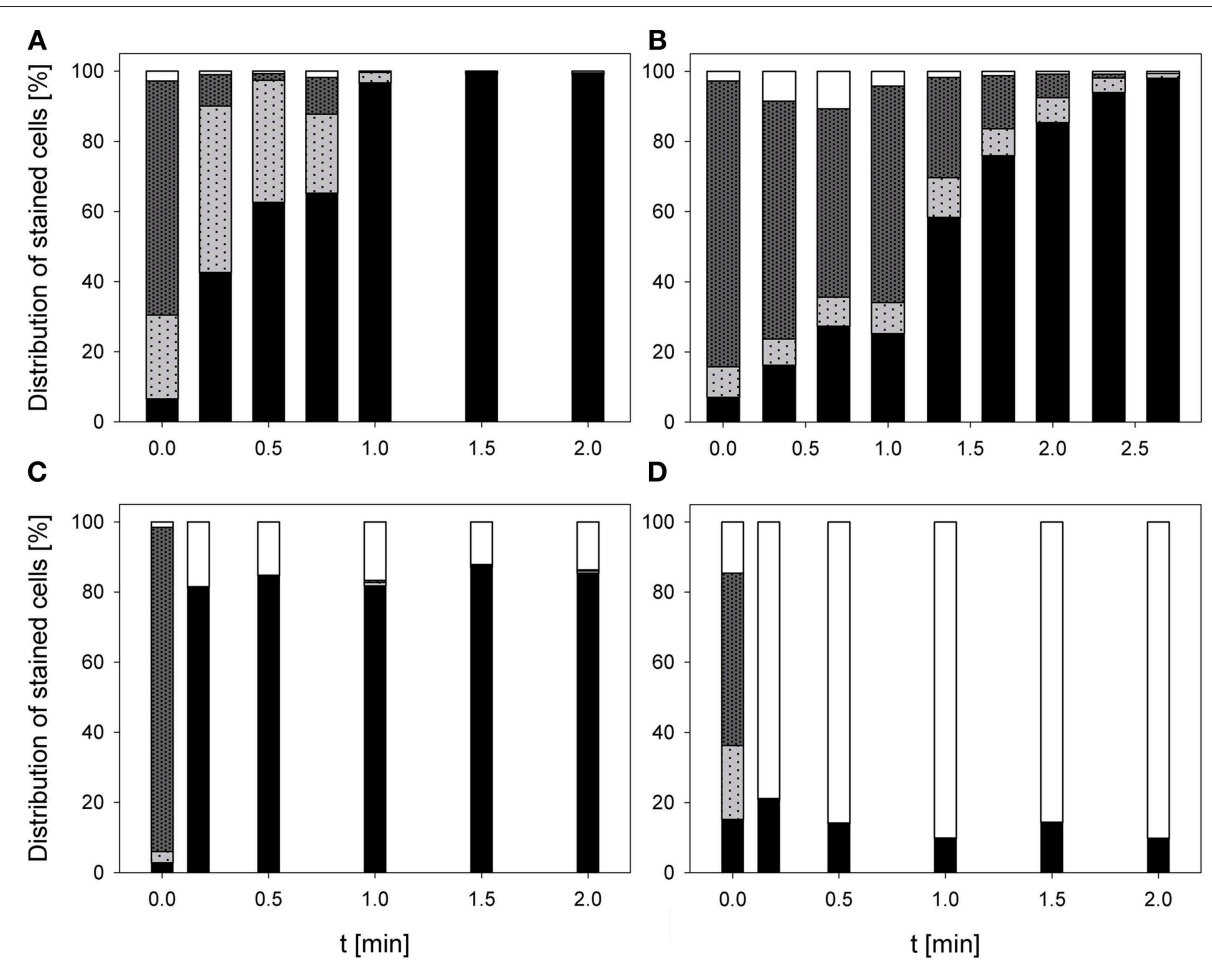

FIGURE 7 | Esterase activity and membrane integrity of $P$. carotovorum after PAA treatment [(A) $10^{\circ} \mathrm{C}, 0.25 \%$ PAA], CAPP treatment [(B) 20 W], and treatment with ozonated water [(C) $2.8 \mathrm{mg} \mathrm{I}^{-1} \mathrm{O}_{3}(-)$; (D) $\mathbf{3 . 8} \mathrm{mg} \mathrm{I}^{-1} \mathrm{O}_{3}(+)$ ]. Black bars representing permeabilized cells without esterase activity; dotted gray bars representing permeabilized cells with esterase activity, dotted light gray bar representing intact cells with esterase activity, and white bars representing cells without fluorescence/cell fragments.

PI-labeled fraction was not able to form colonies on agar plates (Grégori et al., 2001). The predominant fraction of L. innocua and $P$. carotovorum cells is permeabilized indicating that these cells were not completely destroyed by the ozone treatment. However, the unstained fraction of L. innocua cells was higher than the unstained fraction of $P$. carotovorum which lead to the assumption that a much greater number of the population of L. innocua was destroyed completely. The observed damage of Gram-negative and Gram-positive bacteria cells is consistent with the observations of Thanomsub et al. (2002). According to the literature, Gram-Positive bacteria are more sensitive to ozone than Gram-negative bacteria (Tiwari, 2012). In our study, the results of the plate count methods showed the highest sensitivity of $P$. carotovorum against ozone while the highest amount of intact cells was observed by flow cytometry. Thus, the loss of culturability of $P$. carotovorum cells is not directly correlated with the loss of membrane integrity. Different results were obtained after ozone treatment stopped by $\mathrm{Na}_{2} \mathrm{~S}_{2} \mathrm{O}_{3}$ in comparison to the results obtained after ozone treatment stopped by shaking. For all tested bacteria a high amount of unstained cells were detected after ozone treatment. Again, P. carotovorum showed the highest percentage of intact cells and L. innocua the lowest percentage of intact cells. The high number of unstained cells suggests a complete destruction of bacteria cells after ozone treatment. This is inconsistent with the results obtained by plate count method because a high number of viable bacteria were detected while flow cytometric analyses of membrane integrity suggest complete destruction of cells. This implies that the unstained fraction of cells cannot necessarily be related to destroyed cells. It is also possible that a flocculation of cellular proteins and an oxidation of double-bonds (Kim et al., 1999) restricted the dye uptake without affecting the culturability. Zhang et al. (2011) showed that Pseudomonas aeruginosa remained intact after treatment with ozone and they suggested that the inactivation is due to increased cytoplasmic membrane permeability and cytoplasm coagulation. Alternatively, the unstained cells may have been completely destroyed cells and cell lyses occurred while the permeabilized fraction may be able to form colonies on a medium because permeabilization of cells is reversible. A reversible pore formation has been described for bacteria treated with pulsed electric fields (Garcia et al., 2007). While the ozone improved cell permeability and enabled the uptake of PI, the availability of nutrients in terms of $\mathrm{Na}_{2} \mathrm{~S}_{2} \mathrm{O}_{3}$ can be metabolically used to support the growth of bacteria on a cultivating medium. These results clearly indicate that membrane integrity measurements cannot give reliable prediction of cell viability. A proposed cause of bacterial death due to ozone treatment is the oxidation of sulfhydryl groups in enzymes (Kim et al., 1999). However, the cF-fluorescence intensity of bacteria is very low after ozone treatment indicating a small amount of hydrolyzed cFDA due to an inactivation of esterase. This supports the assumption that the esterase is oxidized by ozone. Alternatively, cFDA may be 

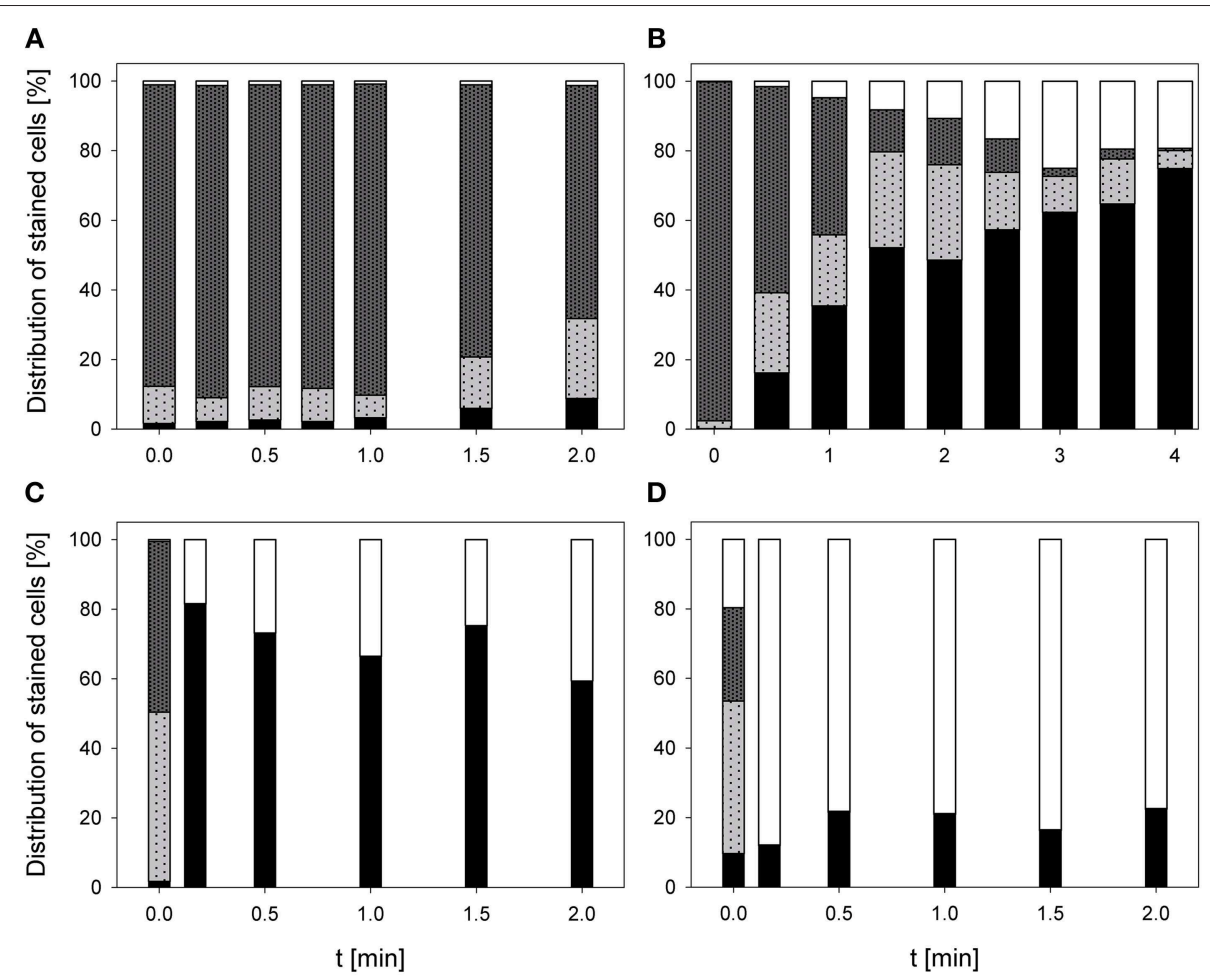

FIGURE 8 | Esterase activity and membrane integrity of $L$. innocua after PAA treatment [(A) $10^{\circ} \mathrm{C}, 0.25 \%$ PAA], CAPP treatment [(B) 20 W], treatment with ozonated water $\left[(C) 3.42 \mathrm{mg} \mathrm{I}^{-1} \mathrm{O}_{3}(-)\right.$; (D) $3.8 \mathrm{mg} \mathrm{I}^{-1} \mathrm{O}_{3}(+)$ ]. Black bars representing permeabilized cells without esterase activity; dotted gray bars representing permeabilized cells with esterase activity, dotted light gray bar representing intact cells with esterase activity, and white bars representing cells without fluorescence/cell fragments.

hydrolyzed by esterase but due to the permeabilization of cells $\mathrm{cF}$ cannot be retained within the cells. The centrifugation step to remove surplus cFDA may also remove the hydrolyze product $\mathrm{cF}$ which could lead to an underestimation of esterase activity. But on the other hand the percentage of permeabilized cells with esterase activity increased. This leads to the assumption that the cell membrane is affected by the ozone before the esterase is affected. It has been shown that a short-time exposure of $E$. coli to ozone led to membrane damage while a longtime exposure affects the intracellular components (Komanapalli and Lau, 1996). Esterase activity of bacteria was also tested after ozone treatment and quenching of ozone by $\mathrm{Na}_{2} \mathrm{~S}_{2} \mathrm{O}_{3}$. No esterase activity was observed after 0.17 min ozone treatment for all tested bacteria. Similar to the results obtained by the measurement of membrane integrity, the predominant fraction of cells remained unstained. This implies that the unstained fraction represents completely ruptured cells and that cell lyses occurred. However, the number of culturable bacteria is not neglectable and this contradicts with the presence of ruptured cells. Therefore, it is more likely that cell permeabilization measured by PI uptake is reversible and cells were able to form colonies on agar medium in the presence of nutrient. The oxidation of phospholipids and proteins in cell membranes is shown to alter the regulation of cell permeability without affecting cell permeability (Cronan and Vagelos, 1972). Thus, the uptake of dyes may be prevented resulting in a high percentage of unstained cells. The generation of membrane potential by tested bacteria was restricted after ozone treatment at different concentrations but the red/green $\operatorname{DiOC}_{2}(3)$ ratio was $>1$ indicating that the cells were not completely depolarized after ozone treatment. The depolarization of the cells increased with increasing ozone concentration. However, the highest membrane potential was observed for bacteria cells after ozone treatment $\left(3.8 \mathrm{mg} \mathrm{l}^{-1}\right)$ stopped by the addition of sodium thiosulfate. This implies that the cells are still able to generate membrane potential after ozone treatment although the application of TO/PI and cFDA/PI did not clearly indicate cell viability. It is not possible to distinguish which cells were able to generate membrane potential after ozone treatment because the measurement represents the average of membrane potential of a population and not the membrane potential of single cells. According to Davidson and Branden (1981) the mode of microbial inactivation of ozone is categorized into three groups: (i) cell membrane is permeabilized and loss of cellular compounds occurs; (ii) inactivation of essential enzymes; and (iii) destruction or functional inactivation of genetic material. After ozone treatment the application of fluorescent dyes did not clearly differentiate between viable, sublethally damaged, and lethally damaged cells. A high fraction of unstained cells restricted the interpretation of physiological properties. Nevertheless, the 
TABLE 4 | Statistical measures and parameter values obtained from GlnaFit Version 1.6 and SigmaPlot13 for experimental data of inactivated E. coli.

\begin{tabular}{|c|c|c|c|c|}
\hline Target site & Model & $k_{\max }\left[1 \min ^{-1}\right]$ & RMSE & $R^{2}$ \\
\hline \multicolumn{5}{|l|}{$0.25 \%$ PAA } \\
\hline Microbial reduction & log-linear regression + tailing & $145.62 \pm 1.1^{*} 10^{10}$ & 0.44 & 0.98 \\
\hline Decrease of intact cells & log-linear regression & $6.35 \pm 3.02$ & 2.26 & 0.47 \\
\hline Membrane permeabilization & Gompertz & $0.23 \pm 0.67$ & n.s. & 0.98 \\
\hline Microbial reduction & log-linear regression + tailing & $98.75 \pm 0.00$ & 0.00 & 1.00 \\
\hline Loss of membrane potential & log-linear regression + tailing & $101.48 \pm 21.53$ & 1.00 & 1.00 \\
\hline Decrease of intact cells & log-linear regression & $54.98 \pm 46.20$ & 34.59 & 0.29 \\
\hline Membrane permeabilization & Gompertz & $0.01 \pm 4.2^{*} 10^{5}$ & n.s. & 0.70 \\
\hline Decrease of esterase activity & log-linear regression & $33.21 \pm 44.88$ & 34.17 & 0.12 \\
\hline Membrane permeabilization & Gompertz & $-0.02 \pm 1.49^{*} 10^{6}$ & n.s. & 0.27 \\
\hline Decrease of esterase activity & log-linear regression & $54.35 \pm 42.98$ & 32.73 & 0.29 \\
\hline \multicolumn{5}{|l|}{20 W CAPP } \\
\hline Microbial reduction & log-linear regression + tailing & $1.29 \pm 0.23$ & 0.27 & 0.89 \\
\hline Loss of membrane potential & log-linear regression + tailing & $0.61 \pm 1.36$ & 0.73 & 0.25 \\
\hline Decrease of intact cells & log-linear regression & $30.45 \pm 1.94$ & 3.27 & 0.97 \\
\hline Membrane permeabilization & Gompertz & $1.16 \pm 1.66$ & n.s. & 0.94 \\
\hline Decrease of esterase activity & log-linear regression & $9.43 \pm 5.49$ & 9.24 & 0.30 \\
\hline
\end{tabular}

n.s., not specified.

obtained data were modeled in order to compare the different inactivation treatments and to describe the mode of action of ozone.

To investigate the inactivation mechanism of CAPP on E. coli, L. innocua, and P. carotovorum inoculated on a polysaccharide gel flow cytometric analyses were performed after treatment. In contrast to previous experiments (Fröhling et al., 2012a), L. innocua was more sensitive to CAPP treatment than E. coli. A possible explanation can be the different growth conditions of L. innocua in both studies which implies that the success of inactivation is highly dependent on the physiological status of the bacteria. E. coli was also more resistant against CAPP treatment than $P$. carotovorum. Similar to the treatment with ozonated water the CAPP showed different mode of actions against the tested bacteria whereas the greatest differences were detected between Gram-negative and Gram-positive bacteria. Different sensitivity of bacteria was also found by Baier et al. (2015). They showed that CAPP treatment has a different impact on three E. coli serovars tested. At $20 \mathrm{~W}$ the percentage of intact $L$. innocua cells decreased but the percentage of permeabilized cells did not increase proportionally. The large amount of unstained cells/cell fragments may indicate a complete rupture of the cell membrane and associated cell lyses. Another explanation for the unstained cells/cell fragments is that the RNA and DNA were affected by the treatment. This assumption is supported by the significant increase in mean TO fluorescence intensity during plasma treatment. The plasma induced inactivation of Citrobacter freundii in apple juice is based on the cell permeabilization due to degradation of specific proteins and lipids. This cell permeabilization may enable the reactive compounds to penetrate into the cells and damage the RNA and possibly the DNA (Surowsky et al., 2014a). However, it is not clear whether the RNA and DNA damage is caused by UV radiation or due to oxidation by oxygen radicals as both of these have been suggested as possible inactivation mechanisms for high pressure plasma. Previous experiments showed that the UV irradiation generated by a similar plasma jet had minor influence on the bacteria (Brandenburg et al., 2007). However, argon supported the UV transmission and UV can support the inactivation. In contrast, the percentage of unstained Gram-negative bacteria remained almost constant after plasma treatment. The decrease of TO-intensity with increasing treatment time may be the result of enhanced membrane permeabilization resulting in competitive intercalating of PI and TO with DNA and quenching of TO-fluorescence by the PI-fluorescence.

Modeling of the flow cytometric data showed a different sensitivity of the bacteria to the applied treatment and that different target sites of the bacteria were affected by the treatments. The loss of culturability of E. coli was faster after PAA and $\mathrm{O}_{3}$ treatment when compared to CAPP treatment 
TABLE 5 | Statistical measures and parameter values obtained from GInaFit Version 1.6 and SigmaPlot13 for experimental data of inactivated $P$. carotovorum.

\begin{tabular}{|c|c|c|c|c|}
\hline Target site & Model & $k_{\max }\left[1 \min ^{-1}\right]$ & RMSE & $R^{2}$ \\
\hline \multicolumn{5}{|l|}{$0.25 \%$ PAA } \\
\hline Microbial reduction & log-linear regression + tailing & $32.19 \pm 0.60$ & 0.05 & 1.00 \\
\hline Loss of membrane potential & log-linear regression + tailing & $72.32 \pm 4.54$ & 0.01 & 1.00 \\
\hline Decrease of intact cells & log-linear regression & $104.46 \pm 15.74$ & 11.81 & 0.90 \\
\hline Membrane permeabilization & Gompertz & $0.01 \pm 4.38^{*} 10^{5}$ & n.s. & 0.97 \\
\hline Decrease of esterase activity & log-linear regression & $49.61 \pm 27.64$ & 20.73 & 0.39 \\
\hline \multicolumn{5}{|l|}{$2.8 \mathrm{mg} \mathrm{I}^{-1} \mathrm{O}_{3}(-)$} \\
\hline Microbial reduction & log-linear regression + tailing & $155.13 \pm 3.62$ & 0.00 & 1.00 \\
\hline Loss of membrane potential & log-linear regression + tailing & $184.35 \pm 6.25^{*} 10^{12}$ & 0.01 & 1.00 \\
\hline Decrease of intact cells & log-linear regression & $53.31 \pm 47.12$ & 35.88 & 0.24 \\
\hline Membrane permeabilization & Gompertz & $0.05 \pm 5.56$ & n.s. & 1.00 \\
\hline Decrease of esterase activity & log-linear regression & $59.24 \pm 46.67$ & 35.54 & 0.29 \\
\hline \multicolumn{5}{|l|}{$3.8 \mathrm{mg} \mathrm{I}^{-1} \mathrm{O}_{3}(+)$} \\
\hline Microbial reduction & log-linear regression + tailing & $42.86 \pm 16.88$ & 0.82 & 0.86 \\
\hline Loss of membrane potential & log-linear regression + tailing & \# & \# & \# \\
\hline Decrease of intact cells & log-linear regression & $55.69 \pm 42.25$ & 31.17 & 0.30 \\
\hline Membrane permeabilization & Gompertz & $-2.05 \pm 20.44$ & n.s. & 0.97 \\
\hline Decrease of esterase activity & log-linear regression & $31.78 \pm 24.79$ & 18.88 & 0.29 \\
\hline \multicolumn{5}{|l|}{20 W CAPP } \\
\hline Microbial reduction & log-linear regression + tailing & $9.5 \pm 0.93$ & 0.69 & 0.94 \\
\hline Loss of membrane potential & log-linear regression + tailing & $1.61 \pm 0.73$ & 0.0975 & 0.8178 \\
\hline Decrease of intact cells & log-linear regression & $73.57 \pm 10.53$ & 11.61 & 0.88 \\
\hline Membrane permeabilization & Gompertz & $0.39 \pm 0.12$ & n.s. & 0.98 \\
\hline Decrease of esterase activity & log-linear regression & $76.72 \pm 7.53$ & 8.45 & 0.93 \\
\hline
\end{tabular}

\# Kinetic could not be described with the applied model.

n.s., not specified.

whereas loss of culturability of P. carotovorum and L. innocua first occurred after ozone treatment followed by PAA and CAPP treatment. The membrane depolarization of E. coli and $P$. carotovorum was faster after ozone treatment followed by PAA treatment and CAPP treatment. In contrast, membrane depolarization first occurred for the PAA treatment of $L$. innocua occurred followed by CAPP and ozone treatment. Cell membrane permeabilization of $E$. coli and L. innocua occurred faster after CAPP treatment followed by PAA treatment and ozone treatment. Similar results were obtained for the cell membrane permeabilization of $P$. carotovorum with the exception that the permeabilization occurred quicker using $\mathrm{O}_{3}(-)$ than PAA treatment. The esterase activity of $L$. innocua and $P$. carotovorum was faster affected using CAPP treatment followed by $\mathrm{O}_{3}(-)$, PAA, and then $\mathrm{O}_{3}(+)$ treatment whereas esterase of $E$. coli was faster inactivated by PAA followed by ozone treatment and finally CAPP treatment. Due to the high percentage of unstained cells and double-stained cells which were not considered in the modeling an overestimation or underestimation of the rates of physiological changes may be derived. It could not be verified if the unstained fraction after the treatments corresponds to complete ruptured cells or to cells that still have intact physiological properties, but which were not detected with the applied fluorescent dyes due to restricted dye uptake. It had to be taken into account that double-stained cells representing on one hand slightly permeabilized cells, and on the other hand permeabilized cells with esterase activity were not considered in the mathematical models. This may lead to an underestimation of cell permeabilization and overestimation of the reduction of esterase activity.

The inactivation rate for CAPP treatment is longer when compared with PAA and ozone treatment. Although, it should be noted that the comparison of PAA, ozone, and CAPP treatment was restricted, bacteria cells were treated with PAA and ozone in suspension whereas bacteria cells treated with CAPP were adherent on a surface (because of the formation of different bacteria layers on the surface of the gel, the superficial bacteria layer may have protective effects against the lowest bacteria layer resulting in reduced inactivation). However, the CAPP treatment procedure is more related to food surface decontamination than the other tested treatment procedures. The use of flow cytometric measurements to characterize different inactivation treatments enables the examination of inactivation effects at a single cell level within a short time. With the applied fluorescent dyes it was possible to evaluate the membrane integrity, esterase activity, pump activity, and membrane potential of Gram-negative and Gram-positive bacteria after the different inactivation treatments used in this study. It was shown that the bacteria were not 
TABLE 6 | Statistical measures and parameter values obtained from GInaFit Version 1.6 and SigmaPlot13 for experimental data of inactivated $L$. innocua.

\begin{tabular}{|c|c|c|c|c|}
\hline Target site & Model & $k_{\max }\left[1 \min ^{-1}\right]$ & RMSE & $R^{2}$ \\
\hline \multicolumn{5}{|l|}{$0.25 \%$ PAA } \\
\hline Microbial reduction & log-linear regression + tailing & $\#$ & $\#$ & $\#$ \\
\hline Decrease of intact cells & log-linear regression & $50.06 \pm 19.88$ & 14.91 & 0.56 \\
\hline Membrane permeabilization & Gompertz & $0.15 \pm 2.33^{*} 10^{6}$ & n.s. & 0.98 \\
\hline Microbial reduction & log-linear regression + tailing & $212.36 \pm 1.20^{*} 10^{10}$ & 0.35 & 0.99 \\
\hline Loss of membrane potential & log-linear regression + tailing & $14.31 \pm 7.4$ & 0.08 & 0.91 \\
\hline Decrease of intact cells & log-linear regression & $54.10 \pm 42.31$ & 32.22 & 0.29 \\
\hline Membrane permeabilization & Gompertz & $-0.21 \pm 6.04^{*} 10^{6}$ & n.s. & 0.13 \\
\hline Decrease of esterase activity & log-linear regression & $31.69 \pm 24.8$ & 18.89 & 0.29 \\
\hline Decrease of intact cells & log-linear regression & $30.15 \pm 23.49$ & 17.89 & 0.29 \\
\hline Membrane permeabilization & Gompertz & $-0.20 \pm \inf$ & n.s. & 0.93 \\
\hline Decrease of esterase activity & log-linear regression & $17.34 \pm 13.56$ & 10.33 & 0.29 \\
\hline \multicolumn{5}{|l|}{20 W CAPP } \\
\hline Microbial reduction & log-linear regression + tailing & $3.3 \pm 1.46$ & 0.44 & 0.98 \\
\hline Loss of membrane potential & log-linear regression + tailing & $57.58 \pm 2.19^{*} 10^{9}$ & 0.05 & 1.00 \\
\hline Decrease of intact cells & log-linear regression & $42.63 \pm 7.82$ & 13.16 & 0.81 \\
\hline Membrane permeabilization & Gompertz & $0.45 \pm 0.18$ & n.s. & 0.99 \\
\hline Decrease of esterase activity & log-linear regression & $48.60 \pm 10.22$ & 17.95 & 0.73 \\
\hline
\end{tabular}

\#Kinetic could not be described with the applied model.

n.s., not specified.

homogeneously inactivated by the treatments tested because different cell populations were detected by flow cytometry. The reliability of measurements is dependent on the inactivation processes applied. In case of complete membrane rupture and cell lyses the application of fluorescent dyes seems to be restricted because a high amount of undefined fluorescence is detected. Furthermore, as a result of the damage of intracellular components the applied fluorescent dyes could not intercalate or could not be metabolized. This also leads to a high amount of unstained cells which may result in an overestimation or underestimation of inactivation effects. Nevertheless, it was shown that flow cytometric measurements provide important information of bacteria cell status after different inactivation treatments within a short time. In a first approach, the membrane integrity was modeled with the Gompertz model or a logistic and esterase activity and membrane potential were modeled with the GInaFiT tool. Thus, the determination of permeabilization, depolarization, and the esterase inactivation rates was possible and facilitates the comparison of different inactivation processes

\section{References}

Alvaro, J. E., Moreno, S., Dianez, F., Santos, M., Carrasco, G., and Urrestarazu, M. (2009). Effects of peracetic acid disinfectant on the postharvest of as well as the prediction of inactivation effects. However, the kinetics of unstained cells and double-stained cells are not considered in the modeling. Thus, important information regarding the inactivation mechanisms could have been lost. It was not possible to model the obtained curves for unstained cells and double-stained cells with common available mathematical models due to the irregular shape of the curves. This may lead to a misinterpretation of inactivation mechanisms. However, the modeling of physiological property changes obtained by flow cytometric measurements can help to predict inactivation kinetics. The detailed knowledge of inactivation effects is absolutely necessary for the implementation of inactivation processes in the production chain.

\section{Acknowledgments}

Part of this work was supported by the COST ACTION FA1202 BacFoodNet. We grateful acknowledge the excellent technical assistance of Susanne Klocke.

some fresh vegetables. J. Food Eng. 95, 11-15. doi: 10.1016/j.jfoodeng.2009. 05.003

Ananta, E., and Knorr, D. (2009). Comparison of inactivation pathways of thermal or high pressure inactivated Lactobacillus rhamnosus ATCC 53103 by 
flow cytometry analysis. Food Microbiol. 26, 542-546. doi: 10.1016/j.fm.2009. 01.008

Ananta, E., Voigt, D., Zenker, M., Heinz, V., and Knorr, D. (2005). Cellular injuries upon exposure of Escherichia coli and Lactobacillus rhamnosus to high-intensity ultrasound. J. Appl. Microbiol. 99, 271-278. doi: 10.1111/j.13652672.2005.02619.x

Antonelli, M., Rossi, S., Mezzanotte, V., and Nurizzo, C. (2006). Secondary effluent disinfection: PAA long term efficiency. Environ. Sci. Technol. 40, 4771-4775. doi: 10.1021/es060273f

Baier, M., Janßen, T., Wieler, L. H., Ehlbeck, J., Knorr, D., and Schlüter, O. (2015). Inactivation of Shiga toxin-producing Escherichia coli O104:H4 using cold atmospheric pressure plasma. J. Biosci. Bioeng. 120, 275-279. doi: 10.1016/j.jbiosc.2015.01.003

Berney, M., Hammes, F., Bosshard, F., Weilenmann, H. U., and Egli, T. (2007). Assessment and interpretation of bacterial viability by using the LIVE/DEAD BacLight kit in combination with flow cytometry. Appl. Environ. Microbiol. 73, 3283-3290. doi: 10.1128/AEM.02750-06

Beuchat, L. R. (1998). Surface Decontamination of Fruits and Vegetables Eaten Raw: A Review. WHO/FSF/FOS/98.2. Geneva: World Health Organization.

Beuchat, L. R., Adler, B. B., and Lang, M. M. (2004). Efficacy of chlorine and a peroxyacetic acid sanitizer in killing Listeria monocytogenes on iceberg and romaine lettuce using simulated commercial processing conditions. J. Food Prot. 67, 1238-1242.

Bigoni, R., Kötzsch, S., Sorlini, S., and Egli, T. (2014). Solar water disinfection by a Parabolic Trough Concentrator (PTC): flow-cytometric analysis of bacterial inactivation. J. Clean. Prod. 67, 62-71. doi: 10.1016/j.jclepro.2013.12.014

Boudam, M. K., Moisan, M., Saoudi, B., Popovici, C., Gherardi, N., and Massines, F. (2006). Bacterial spore inactivation by atmospheric-pressure plasmas in the presence or absence of UV photons as obtained with the same gas mixture. J. Phys. D Appl. Phys. 39, 3494-3507. doi: 10.1088/0022-3727/39/16/S07

Brandenburg, R., Ehlbeck, J., Stieber, M., Von Woedtke, T., Zeymer, J., Schlüter, O., et al. (2007). Antimicrobial treatment of heat sensitive materials by means of atmospheric pressure rf-driven plasma jet. Contrib. Plasma Phys. 47, 72-79. doi: 10.1002/ctpp.200710011

Bunthof, C. J. (2002). Flow Cytometry, Fluorescent Probes, and Flashing Bacteria. Wageningen: Wageningen University.

Bunthof, C. J., and Abee, T. (2002). Development of a flow cytometric method to analyze subpopulations of bacteria in probiotic products and dairy starters. Appl. Environ. Microbiol. 68, 2934-2942. doi: 10.1128/AEM.68.6.29342942.2002

Bußler, S., Herppich, W. B., Neugart, S., Schreiner, M., Ehlbeck, J., Rohn, S., et al. (2015a). Impact of cold atmospheric pressure plasma on physiology and flavonol glycoside profile of peas (Pisum sativum 'Salamanca'). Food Res. Int. 76, 132-141. doi: 10.1016/j.foodres.2015.03.045

Bußler, S., Steins, V., Ehlbeck, J., and Schlüter, O. (2015b). Impact of thermal treatment versus cold atmospheric plasma processing on the techno-functional protein properties from Pisum sativum 'Salamanca'. J. Food Eng. doi: 10.1016/j.jfoodeng.2015.05.036. [Epub ahead of print].

Cronan, J. E., and Vagelos, P. R. (1972). Metabolism and function of the membrane phospholipids of Escherichia coli. Biochim. Biophys. Acta 265, 25-60. doi: 10.1016/0304-4157(72)90018-4

Da Silveira, M. G., and Abee, T. (2009). Activity of ethanol-stressed Oenococcus oeni cells: a flow cytometric approach. J. Appl. Microbiol. 106, 1690-1696. doi: 10.1111/j.1365-2672.2008.04136.x

Davidson, P. M., and Branden, A. L. (1981). Anti-microbial activity of nonhalogenated phenolic-compounds. J. Food Protect. 44, 623-632.

Doyle, M. P., and Erickson, M. C. (2008). Summer meeting 2007 - the problems with fresh produce: an overview. J. Appl. Microbiol. 105, 317-330. doi: 10.1111/j.1365-2672.2008.03746.x

Ehlbeck, J., Schnabel, U., Polak, M., Winter, J., Woetke, T. V., Brandenburg, R., et al. (2011). Low temperature atmospheric pressure plasma sources for microbial decontamination. J. Phys. D Appl. Phys. 44:013002. doi: 10.1088/0022-3727/44/1/013002

El Shafie, A., Fouda, M. M. G., and Hashem, M. (2009). One-step process for bioscouring and peracetic acid bleaching of cotton fabric. Carbohydr. Polym. 78, 302-308. doi: 10.1016/j.carbpol.2009.04.002

Fröhling, A., Baier, M., Ehlbeck, J., Knorr, D., and Schlüter, O. (2012a). Atmospheric pressure plasma treatment of Listeria innocua and Escherichia coli at polysaccharide surfaces: inactivation kinetics and flow cytometric characterization. Innovative Food Sci. Emerg. Technol. 13, 142-150. doi: 10.1016/j.ifset.2011.11.002

Fröhling, A., Klocke, S., Hausdorf, L., Klocke, M., and Schlüter, O. (2012b). A method for viability testing of Pectobacterium carotovorum in postharvest processing by means of flow cytometry. Food Bioprocess Technol. 5, 2871-2879. doi: 10.1007/s11947-011-0749-6

García, D., Gómez, N., Mañas, P., Raso, J., and Pagán, R. (2007). Pulsed electric fields cause bacterial envelopes permeabilization depending on the treatment intensity, the treatment medium $\mathrm{pH}$ and the microorganism investigated. Int. J. Food Microbiol. 113, 219-227. doi: 10.1016/j.ijfoodmicro.2006. 07.007

Gaunt, L. F., Beggs, C. B., and Georghiou, G. E. (2006). Bactericidal action of the reactive species produced by gas-discharge nonthermal plasma at atmospheric pressure: a review. IEEE Trans. Plasma Sci. 34, 1257-1269. doi: 10.1109/TPS.2006.878381

Geeraerd, A. H., Valdramidis, V. P., and Van Impe, J. F. (2005). GInaFiT, a freeware tool to assess non-log-linear microbial survivor curves. Int. J. Food Microbiol. 102, 95-105. doi: 10.1016/j.ijfoodmicro.2004.11.038

Graham, D. (1997). Use of ozone for food processing. Food Technol. 51, 72-76.

Grégori, G., Citterio, S., Ghiani, A., Labra, M., Sgorbati, S., Brown, S., et al. (2001). Resolution of viable and membrane-compromised bacteria in freshwater and marine waters based on analytical flow cytometry and nucleic acid double staining. Appl. Environ. Microbiol. 67, 4662-4670. doi: 10.1128/AEM.67.10.4662-4670.2001

Guzel-Seydim, Z., Bever, P., and Greene, A. (2004). Efficacy of ozone to reduce bacterial populations in the presence of food components. Food Microbiol. 21, 475-479. doi: 10.1016/j.fm.2003.10.001

Hammes, F., Berney, M., Wang, Y. Y., Vital, M., Köster, O., and Egli, T. (2008). Flow-cytometric total bacterial cell counts as a descriptive microbiological parameter for drinking water treatment processes. Water Res. 42, 269-277. doi: 10.1016/j.watres.2007.07.009

Haugland, R. P. (1994). Spectra of fluorescent dyes used in flow cytometry. Methods Cell Biol. 42, 641-663.

Herrero, M., Quirós, C., García, L. A., and Díaz, M. (2006). Use of flow cytometry to follow the physiological states of microorganisms in cider fermentation processes. Appl. Environ. Microbiol. 72, 6725-6733. doi: 10.1128/AEM.01 183-06

Hewitt, C. J., and Nebe-Von-Caron, G. (2004). The application of multiparameter flow cytometry to monitor individual microbial cell physiological status. Adv. Biochem. Eng. Biotechnol. 89, 197-223. doi: 10.1007/ b93997

Johnson, S., Nguyen, V., and Coder, D. (2013). Assessment of cell viability. Curr. Protoc. Cytom. 64:9.2.1-9.2.26. doi: 10.1002/0471142956.cy0902s64

Joux, F., and Lebaron, P. (2000). Use of fluorescent probes to assess physiological functions of bacteria at single-cell level. Microb. Infect. 2, 1523-1535. doi: 10.1016/S1286-4579(00)01307-1

Joyce, E., Al-Hashimi, A., and Mason, T. J. (2011). Assessing the effect of different ultrasonic frequencies on bacterial viability using flow cytometry. J. Appl. Microbiol. 110, 862-870. doi: 10.1111/j.1365-2672.2011. 04923.x

Kader, A. A. (2005). Increasing food availability by reducing postharvest losses of fresh produce. Acta Hortic. (ISHS) 682, 2169-2176. doi: 10.17660/actahortic.2005.682.296

Kamat, A. S., and Nair, P. M. (1996). Identification of Listeria innocua as a biological indicator for inactivation of $L$. monocytogenes by some meat processing treatments. Lebensm. Wiss. Technol. 29, 714-720. doi: 10.1006/fstl.1996.0111

Khadre, M., and Yousef, A. E. (2001). Sporicidal action of ozone and hydrogen peroxide: a comparative study. Int. J. Food Microbiol. 71, 131-138. doi: 10.1016/S0168-1605(01)00561-X

Kim, H., Ryu, J. H., and Beuchat, L. R. (2006). Survival of Enterobacter sakazakii on fresh produce as affected by temperature, and effectiveness of sanitizers for its elimination. Int. J. Food Microbiol. 111, 134-143. doi: 10.1016/j.ijfoodmicro.2006.05.021

Kim, J.-G., Yousef, A. E., and Dave, S. (1999). Application of ozone for enhancing the microbiological safety and quality of foods: a review. J. Food Prot. 62, 1071-1087. 
Kim, J.-G., Yousef, A. E, and Khadre, M. A. (2003). Ozone and its current and future application in the food industry. Adv. Food Nutr. Res. 45, 167-218. doi: $10.1016 /$ S1043-4526(03)45005-5

Kitis, M. (2004). Disinfection of wastewater with peracetic acid: a review. Environ. Int. 30, 47-55. doi: 10.1016/S0160-4120(03)00147-8

Koivunen, J., and Heinonen-Tanski, H. (2005). Peracetic acid (PAA) disinfection of primary, secondary and tertiary treated municipal wastewaters. Water Res. 39, 4445-4453. doi: 10.1016/j.watres.2005.08.016

Komanapalli, I. R., and Lau, B. H. S. (1996). Ozone-induced damage of Escherichia coli K-12. Appl. Microbiol. Biotechnol. 46, 610-614. doi: 10.1007/s0025300 50869

Kunigk, L., and Almeida, M. C. B. (2001). Action of peracetic acid on Escherichia coli and Staphylococcus aureus in suspension and on stainless steel surfaces. Braz. J. Microbiol. 32, 38-41. doi: 10.1590/S1517-838220010001 00009

Laroussi, M. (2002). Nonthermal decontamination of biological media by atmospheric-pressure plasmas: review, analysis and prospects. IEEE Trans. Plasma Sci. 30, 1409-1415. doi: 10.1109/TPS.2002.804220

Laroussi, M. (2005). Low temperature plasma-based sterilization: overview and state-of-the-art. Plasma Processes Polym. 2, 391-400. doi: 10.1002/ppap.200400078

Luscher, C., Balasa, A., Fröhling, A., Ananta, E., and Knorr, D. (2004). Effect of high-pressure-induced ice I-to-ice III phase transitions on inactivation of Listeria innocua in frozen suspension. Appl. Environ. Microbiol. 70, 4021-4029. doi: 10.1128/AEM.70.7.4021-4029.2004

Luukkonen, T., Teeriniemi, J., Prokkola, H., Rämö, J., and Lassi, U. (2014). Chemical aspects of peracetic acid based wastewater disinfection. Water SA 40, 73-80. doi: 10.4314/wsa.v40i1.9

Mahapatra, A. K., Muthukumarappan, K., and Julson, J. (2005). Applications of ozone, bacteriocins and irradiation in food processing: a review. Crit. Rev. Food Sci. Nutr. 45, 447-461. doi: 10.1080/10408390591034454

Mathys, A., Chapman, B., Bull, M., Heinz, V., and Knorr, D. (2007). Flow cytometric assessment of Bacillus spore response to high pressure and heat. Innovative Food Sci. Emerg. Technol. 8, 519-527. doi: 10.1016/j.ifset.2007.06.010

Mezzanotte, V., Antonelli, M., Azzellino, A., Citterio, S., and Nurizzo, C. (2003). Secondary effluent disinfection by peracetic acid (PAA): microrganism inactivation and regrowth, preliminary results. Water Sci. Technol. 3, 269-275.

Miller, F. A., Silva, C. L. M., and Brandao, T. R. S. (2013). A review on ozone-based treatments for fruit and vegetables preservation. Food Eng. Rev. 5, 77-106. doi: 10.1007/s12393-013-9064-5

Misra, N. N., Kaur, S., Tiwari, B. K., Kaur, A., Singh, N., and Cullen, P. J. (2015). Atmospheric pressure cold plasma (ACP) treatment of wheat flour. Food Hydrocoll. 44, 115-121. doi: 10.1016/j.foodhyd.2014.08.019

Moisan, M., Barbeau, J., Crevier, M.-C., Pelletier, J., Philip, N., and Saoudi, B. (2002). Plasma sterilization. Methods and mechanisms. Pure Appl. Chem. 74, 349-358. doi: 10.1351/pac200274030349

Moisan, M., Barbeau, J., Moreau, S., Pelletier, J., Tabrizian, M., and Yahia, L. H. (2001). Low-temperature sterilization using gas plasmas: a review of the experiments and an analysis of the inactivation mechanisms. Int. J. Pharm. 226, 1-21. doi: 10.1016/S0378-5173(01)00752-9

Moore, G., Griffith, C., and Peters, A. (2000). Bactericidal properties of ozone and its potential application as a terminal disinfectant. J. Food Prot. 63, 1100-1106.

Moreau, M., Orange, N., and Feuilloley, M. G. J. (2008). Non-thermal plasma technologies: new tools for bio-decontamination. Biotechnol. Adv. 26, 610-617. doi: 10.1016/j.biotechadv.2008.08.001

Novo, D., Perlmutter, N. G., Hunt, R. H., and Shapiro, H. M. (1999). Accurate flow cytometric membrane potential measurement in bacteria using diethyloxacarbocyanine and a ratiometric technique. Cytometry 35, 55-63.

Nygren, J., Svanvik, N., and Kubista, M. (1998). The interactions between the fluorescent dye thiazole orange and DNA. Biopolymers 46, 39-51.

O'Donnell, C., Tiwari, B. K., Cullen, P. J., and Rice, R. G. (2012). Ozone in Food Processing. West Sussex: Wiley-Blackwell.

Ölmez, H., and Kretzschmar, U. (2009). Potential alternative disinfection methods for organic fresh-cut industry for minimizing water consumption and environmental impact. LWT Food Sci. Technol. 42, 686-693. doi: 10.1016/j.lwt.2008.08.001
Park, E., Lee, C., Bisesi, M., and Lee, J. (2014). Efficiency of peracetic acid in inactivating bacteria, viruses, and spores in water determined with ATP bioluminescence, quantitative PCR, and culture-based methods. J. Water Health 12, 13-23. doi: 10.2166/wh.2013.002

Pascual, A., Llorca, I., and Canut, A. (2007). Use of ozone in food industries for reducing the environmental impact of cleaning and disinfection activities. Trends Food Sci. Technol. 18, S29-S35. doi: 10.1016/j.tifs.2006. 10.006

Perry, J. J., and Yousef, A. E. (2011). Decontamination of raw foods using ozonebased sanitization techniques. Annu. Rev. Food Sci. Technol. 2, 281-298. doi: 10.1146/annurev-food-022510-133637

Rasimus, S., Kolari, M., Rita, H., Hoornstra, D., and Salkinoja-Salonen, M. (2011). Biofilm-forming bacteria with varying tolerance to peracetic acid from a paper machine. J. Ind. Microbiol. Biotechnol. 38, 1379-1390. doi: 10.1007/s10295-0100921-4

Rossi, S., Antonelli, M., Mezzanotte, V., and Nurizzo, C. (2007). Peracetic acid disinfection: a feasible alternative to wastewater chlorination. Water Environ. Res. 79, 341-350. doi: 10.2175/106143006X101953

Sapers, G. M. (2001). Efficacy of washing and sanitizing methods for disinfection of fresh fruit and vegetable products. Food Technol. Biotechnol. 39, 305-311.

Schenk, M., Raffellini, S., Guerrero, S., Blanco, G. A., and Maris Alzamora, S. (2011). Inactivation of Escherichia coli, Listeria innocua and Saccharomyces cerevisiae by UV-C light: study of cell injury by flow cytometry. LWT Food Sci. Technol. 44, 191-198. doi: 10.1016/j.lwt.2010.05.012

Schlüter, O., Foerster, J., Geyer, M., Knorr, D., and Herppich, W. (2009). Characterization of high-hydrostatic-pressure effects on fresh produce using chlorophyll fluorescence image analysis. Food Bioprocess Technol. 2, 291-299. doi: 10.1007/s11947-008-0143-1

Schlüter, O., and Fröhling, A. (2014). "NON-THERMAL PROCESSING cold plasma for bioefficient food processing," in Encyclopedia of Food Microbiology, 2nd Edn., ed C. A. B. L. Tortorello (Oxford: Academic Press), 948-953.

Steudler, S., Böhmer, U., Weber, J., and Bley, T. (2015). Biomass measurement by flow cytometry during solid-state fermentation of basidiomycetes. Cytometry $\mathrm{A}$ 87, 176-188. doi: 10.1002/cyto.a.22592

Surowsky, B., Fischer, A., Schlueter, O., and Knorr, D. (2013). Cold plasma effects on enzyme activity in a model food system. Innovative Food Sci. Emerg. Technol. 19, 146-152. doi: 10.1016/j.ifset.2013.04.002

Surowsky, B., Fröhling, A., Gottschalk, N., Schlüter, O., and Knorr, D. (2014a). Impact of cold plasma on Citrobacter freundii in apple juice: inactivation kinetics and mechanisms. Int. J. Food Microbiol. 174, 63-71. doi: 10.1016/j.ijfoodmicro.2013.12.031

Surowsky, B., Schlüter, O., and Knorr, D. (2014b). Interactions of non-thermal atmospheric pressure plasma with solid and liquid food systems: a review. Food Eng. Rev. 7, 82-108. doi: 10.1007/s12393-014-9088-5

Tamburini, S., Ballarini, A., Ferrentino, G., Moro, A., Foladori, P., Spilimbergo, S., et al. (2013). Comparison of quantitative PCR and flow cytometry as cellular viability methods to study bacterial membrane permeabilization following supercritical $\mathrm{CO}_{2}$ treatment. Microbiology 159, 1056-1066. doi: 10.1099/mic.0.063321-0

Thanomsub, B., Anupunpisit, V., Chanphetch, S., Watcharachaipong, T., Poonkhum, R., and Srisukonth, C. (2002). Effects of ozone treatment on cell growth and ultrastructural changes in bacteria. J. Genet. Appl. Microbiol. 48, 193-199. doi: 10.2323 /jgam.48.193

Tiwari, B. K. M., K. (2012). "Ozone in fruit and vegetable processing," in Ozone in Food Processing, eds C. T. O’Donnell, B. K. Tiwari, P. J. Cullen, R. G. Rice (West Sussex: Wiley-Blackwell), 55-80.

Vandekinderen, I., Devlieghere, F., De Meulenaer, B., Ragaert, P., and Van Camp, J. (2009). Optimization and evaluation of a decontamination step with peroxyacetic acid for fresh-cut produce. Food Microbiol. 26, 882-888. doi: 10.1016/j.fm.2009.06.004

Van De Velde, F., Gueemes, D. R., and Pirovani, M. E. (2014). Optimisation of the peracetic acid washing disinfection of fresh-cut strawberries based on microbial load reduction and bioactive compounds retention. Int. J. Food Sci. Technol. 49, 634-640. doi: $10.1111 /$ ijfs. 12346

Vleugels, M., Shama, G., Deng, X. T., Greenacre, E., Brocklehurst, T., and Kong, M. G. (2005). Atmospheric plasma inactivation of biofilm-forming 
bacteria for food safety control. IEEE Trans. Plasma Sci. 33, 824-828. doi: 10.1109/TPS.2005.844524

Wang, H., Feng, H., and Lao, Y. (2006). Dual-phasic inactivation of Escherichia coli $\mathrm{O} 157: \mathrm{H} 7$ with peroxyacetic acid, acidic acid, acidic electrolyzed water and chlorine on cantaloupes and fresh-cut apples. J. Food Saf. 26, 335-347. doi: 10.1111/j.1745-4565.2006.00053.x

Zhang, Y. Q., Wu, Q. P., Zhang, J. M., and Yang, X. H. (2011). Effects of ozone on membrane permeability and ultrastructure in Pseudomonas aeruginosa. J. Appl. Microbiol. 111, 1006-1015. doi: 10.1111/j.1365-2672.2011. 05113.x
Conflict of Interest Statement: The authors declare that the research was conducted in the absence of any commercial or financial relationships that could be construed as a potential conflict of interest.

Copyright (c) 2015 Fröhling and Schlüter. This is an open-access article distributed under the terms of the Creative Commons Attribution License (CC BY). The use, distribution or reproduction in other forums is permitted, provided the original author(s) or licensor are credited and that the original publication in this journal is cited, in accordance with accepted academic practice. No use, distribution or reproduction is permitted which does not comply with these terms. 